United States

Department of

Agriculture

Forest Service

Pacific Northwest

Research Station

Research Paper

PNW-RP-574

November 2007

[4]5]

\section{Growth of Douglas-fir Near Equipment Trails Used for Commercial Thinning in the Oregon Coast Range}

Richard E. Miller, Jim Smith, Paul W. Adams, and Harry W. Anderson

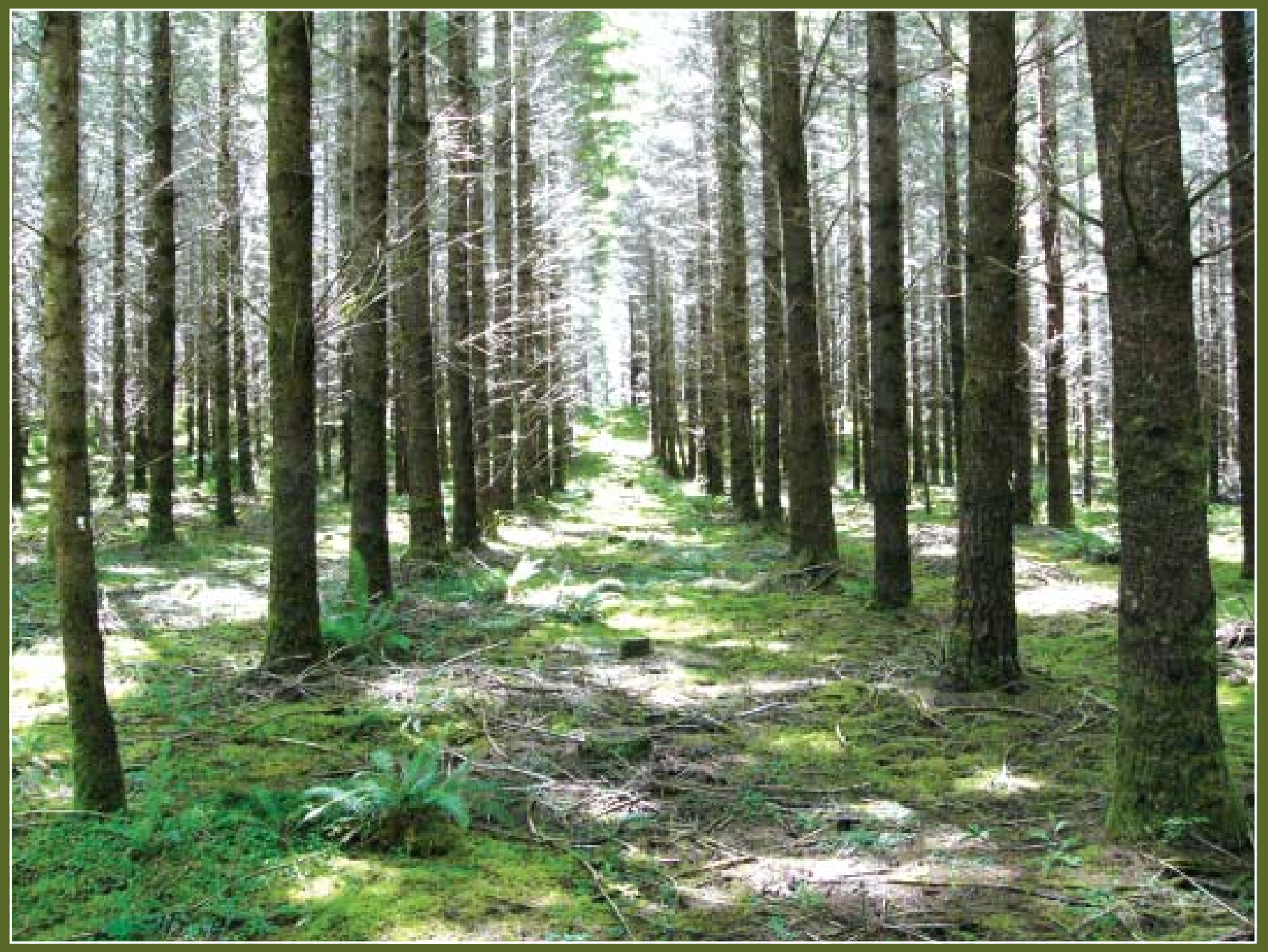


The Forest Service of the U.S. Department of Agriculture is dedicated to the principle of multiple use management of the Nation's forest resources for sustained yields of wood, water, forage, wildlife, and recreation. Through forestry research, cooperation with the States and private forest owners, and management of the national forests and national grasslands, it strives-as directed by Congress-to provide increasingly greater service to a growing Nation.

The U.S. Department of Agriculture (USDA) prohibits discrimination in all its programs and activities on the basis of race, color, national origin, age, disability, and where applicable, sex, marital status, familial status, parental status, religion, sexual orientation, genetic information, political beliefs, reprisal, or because all or part of an individual's income is derived from any public assistance program. (Not all prohibited bases apply to all programs.) Persons with disabilities who require alternative means for communication of program information (Braille, large print, audiotape, etc.) should contact USDA's TARGET Center at (202) 720-2600 (voice and TDD).

To file a complaint of discrimination write USDA, Director, Office of Civil Rights, 1400 Independence Avenue, S.W. Washington, DC 20250-9410, or call (800) 7953272 (voice) or (202) 720-6382 (TDD). USDA is an equal opportunity provider and employer.

\section{Authors}

Richard E. Miller is an emeritus soil scientist and Harry W. Anderson is a forester, U.S. Department of Agriculture, Forest Service, Pacific Northwest Research Station, $362593^{\text {rd }}$ Ave. SW, Olympia, WA 98512-9393; Jim Smith is a forester, Plum Creek Timberlands, L.P., Cottage Grove, OR 97424; and Paul W. Adams is a professor, College of Forestry, Oregon State University, Corvallis, OR 97331. 


\section{Abstract}

Miller, Richard E.; Smith, Jim; Adams, Paul W.; Anderson, Harry W. 2007. Growth of Douglas-fir near equipment trails used for commercial thinning in the Oregon Coast Range. Res. Pap. PNW-RP-574. Portland, OR: U.S. Department of Agriculture, Forest Service, Pacific Northwest Research Station. 33 p.

Soil disturbance is a visually apparent result of using heavy equipment to harvest trees. Subsequent consequences for growth of remaining trees, however, are variable and seldom quantified. We measured tree growth 7 and 11 years after thinning of trees in four stands of coast Douglas-fir (Pseudotsuga menziesii var. menziesii (Mirb. Franco)) where soil disturbance was limited by using planned skid trails, usually on dry soils. The three younger stands had responded to nitrogen fertilizer in the 4 years before thinning, but only one stand showed continued response in the subsequent 7- or 11-year period after thinning. The most consistent pattern observed was greater growth of residual trees located next to skid trails. The older stand also showed greater growth in trees located next to skid trails, whereas tillage of skid trails failed to benefit growth of nearby residual trees for the first 7 years after tillage. We conclude that traffic that compacted soil only on one side of residual trees did not reduce growth of nearby trees.

Keywords: Commercial thinning, coast Douglas-fir, equipment trails, tree growth, mitigation.

\section{Summary}

Tree growth after commercial thinning is influenced by initial tree size, degree of release when neighboring trees are removed, subsequent competition among residual trees, and soil disturbance from heavy equipment.

Our investigations at three locations in the Coast Range of western Oregon sought to answer two questions: Did proximity to trails used by various groundbased logging vehicles affect subsequent growth of coast Douglas-fir (Pseudotsuga menziesii var. menziesii (Mirb. Franco)) trees? At two of these locations, we posed two additional questions: Did past nitrogen $(\mathrm{N})$ fertilization continue to increase growth or influence tree response to equipment traffic?

At Toledo South and Bone Mountain, we investigated response of 20-year-old trees to thinning in plantations of uniformly spaced Douglas-fir. Four years before these thinnings, a fertilization treatment was assigned randomly to 5 of the 10 plots at Toledo South and to 3 of the 6 plots at both Bone Mountain A and B. Urea fertilizer providing $200 \mathrm{lb}$ N/acre was uniformly spread over assigned plots. These 
plantations were commercially thinned after the 1993 growing season. Slash was accumulated and retained on the traffic routes. At Toledo South, the first and every seventh row were removed to provide routes for equipment traffic. In alternate rows between these routes, all trees were cut and removed by extending the harvester boom. No trees were cut in the remaining even-numbered rows, which included rows beside the travel routes. Stand density was reduced from about 600 trees per acre (TPA) to about 300 TPA. At Bone Mountain A and B, every fifth row of the original planting was removed to provide traffic routes for a tracked harvester and a forwarder. Some additional trees in intervening rows were cut and removed by extending the harvester boom. Consequently, tree removal was not uniform as in the purely row-thinning at Toledo South. The original density of 680 TPA was reduced to about 260 TPA (62 percent cut).

After thinning, residual trees were identified in two categories: those located beside traffic routes (position 1) and those located in the interior between traffic routes (position 2). Because some within-row-trees were removed at Bone Mountain $\mathrm{A}$ and $\mathrm{B}$, residual trees in position 1 and position 2 had varying numbers of neighboring or competing trees, ranging from zero to four of the initial eight. On all plots, the number of competing neighbors was fewer in rows beside the trails (position 1) in these two plantations.

Effects of commercial thinning on mean tree breast-height (b.h.) growth (overbark cross-sectional or basal area) were estimated and compared by a fixed-effects analysis of variance (ANOVA) or covariance (COVAR) analyses. An alpha value of 0.10 was used to judge statistical significance.

The position $\mathrm{x}$ fertilizer interaction was statistically nonsignificant at Toledo South and Bone Mountain A and B. We infer that tree response to trails was independent of earlier fertilization. Residual effects of the earlier fertilization remained statistically significant after thinning only at Bone Mountain A (12-percent increase over control), but was not significant at Bone Mountain B and Toledo South (4 percent more and 1 percent less than nonfertilized, respectively). At Bone Mountain A, however, inferences from statistical tests about continued response to earlier fertilization may be confounded by fewer residual trees on fertilized versus nonfertilized plots.

Because slash was deliberately placed on equipment trails, rutting was infrequent and shallow ( $<3$ in). Therefore, we assume that root crushing or severing was not likely to have reduced growth of trees bordering trails. Bole damage also was inconsequential. Trees next to trails at Toledo South averaged about 3 percent faster b.h. growth than trees located farthest from the trails $(\mathrm{p}=0.10)$. At Bone Mountain A and B, b.h. growth of trees next to trails averaged about 14 and 11 percent more, 
respectively, than growth of more distant trees. We speculate that this faster growth is explained by greater release and fewer competing trees near position 1 trees, and those advantages more than offset any negative effects of equipment traffic at Bone Mountain A and B.

The Noti study is in a stand of 58-year-old Douglas-fir that averaged 206 TPA before thinning. Thinning reduced stand density to 70 TPA (66 percent cut) and produced harvested logs averaging 10 inches in diameter. Logging that began in late July was completed by late August. Hot and dry weather reduced soil moisture to less than 20 percent (weight basis) on all skid trails. Whole trees and logs were skidded to roadside landings at the end of seven parallel, planned skid trails spaced about $150 \mathrm{ft}$ apart. In early September 1992, four of these skid trails were tilled with a self-drafting, hydraulically controlled, winged-subsoiler mounted on a large crawler tractor.

Shortly after logging and tillage, a total of 119 residual trees between and near the seven tilled or nontilled skid trails were tagged and measured for diameter at breast height, height, crown characteristics, and distance to neighboring trees, which enabled computation of a competition index. Sampling provided about 40 trees in each of three categories relative to skid trails: tilled, nontilled, and no trail (i.e., thinned but no trail influence). Basal area (BA) growth per tree in 1992 through 1999 was used as the dependent variable in growth analysis. Because tillage resulted in noticeable damage to roots of adjacent trees, a damage index was used to evaluate potential relation with observed growth responses. Soil bulk densities in skid trails and around residual trees were measured with nuclear densiometers shortly after logging, just after tillage, and after seven growing seasons.

Small differences in soil bulk densities were observed 7 years after treatment, and less than 40 percent of the assumed rooting area of individual trees was affected by equipment trails.

After covariance adjustment for differing starting BA, average growth of trees near nontilled trails exceeded that of nontrail trees by about 13 percent and exceeded that of trees near tilled trails by about 22 percent. A second analysis was necessitated because trees near nontilled trails averaged less and were less variable in after-thinning competitive stress index than nontrail and tilled trees, which were similar in both means and ranges of competitive stress index. Despite covariance adjustment of observed means to mitigate this advantage, after-thinning growth of nontilled trees still averaged 14 percent greater than nontrail trees and 6 percent greater than tilled trees. The finding that growth was increased by proximity to nontilled trails was consistent with results at Toledo South and Bone Mountain A 
and B. We suspect that trafficking the clay loam soils at Noti when dry, and limiting compacted area within the stand by using planned skid trails were effective management tactics at this site. Tillage provided no clear benefit to residual trees, at least in the first 7 years after treatment.

We conclude that commercial thinning of these 20- to 60-year-old Douglas-fir stands by using ground-based logging vehicles and planned skid trails usually on dry soils did not reduce, and probably slightly increased tree growth of trail-side residual trees. At the two locations where selected plots were fertilized before thinning, tree response to adjacent trails was independent of the earlier fertilization with $200 \mathrm{lb}$ N/acre as urea.

\title{
Contents
}

\author{
1 Introduction \\ 2 Methods \\ 2 Toledo South and Bone Mountain \\ 7 Noti \\ 10 Results \\ 10 Toledo South \\ 14 Bone Mountain A and B \\ 20 Noti \\ 23 Discussion \\ 25 Toledo South \\ 25 Bone Mountain A and B \\ 26 Noti \\ 27 All Locations \\ 27 Potential Effects of Equipment Trails \\ 29 Continued Effects of Nitrogen Fertilization \\ 30 Conclusions \\ 30 Acknowledgments \\ 31 Metric Equivalents \\ 31 Literature Cited
}




\section{Introduction}

Soil disturbance is a visually apparent result of using heavy equipment to harvest trees. Typical types of soil disturbance from ground-based harvest include displacement, rutting, and compaction. Subsequent consequences of soil disturbance to growth of trees, however, are variable and seldom quantified beyond short-term effects. Despite a persistent need to further quantify tree response to soil disturbance, policies and practices intended to reduce or avoid soil disturbance from logging have been widely adopted on both public and private forest lands in the Pacific Northwest (Adams 2005).

Response of trees to soil disturbance is variable and dependent on soil, climate, and perhaps tree species. Growth of Douglas-fir seedlings (Pseudotsuga menziesii var. menziesii (Mirb. Franco)) planted in compacted and rutted skid trails at three coastal Washington locations with moderate climate was compared to that of nearby seedlings planted on nontrafficked soil. Difference in height growth and tree size in the first decade were small and statistically not different (Miller and others 1996). At eight Oregon Cascade locations with harsher climate, however, average height at year 10 after planting was reduced by about 10 percent (Heninger and others 2002). In northern California with even drier climate, effects of controlled intensity of soil compaction on soil properties and response of young trees differed by soil texture. Compaction of a coarse sandy loam improved young tree growth, but compaction of a clay loam decreased growth, and compaction of a loamy soil had no effect on growth (Gomez and others 2002).

Effects of soil disturbance on growth of residual trees after commercial thinning or other forms of partial harvest in the Pacific Northwest are less researched. Froehlich (1979) reported that coast Douglas-fir having 10 percent or more increase in soil bulk density (BD) in 10 to 40 percent of their assumed rooting area grew 14 percent less in basal area (BA) than residual trees on noncompacted soil. Similarly impacted western hemlock (Tsuga heterophylla (Raf.) Sarg.) also averaged about 15 percent less basal area (BA) growth (Froehlich 1979). Douglas-fir having larger increases in soil BD and greater percentage of root area affected grew 30 percent less than residual trees on nondisturbed soil. Other researchers did not measure tree response, but speculated about growth consequences after commercial thinning based on estimated percentage of the thinned stand in various soil disturbance classes (Murphy 1982), percentage of area with measured increases in soil BD (McNeel and Ballard 1992), or numbers and severity of bole damage (Han and Kellogg 2000, McNeel and Ballard 1992).

Response of trees
to soil disturbance
is variable and
dependent on soil,
climate, and perhaps
tree species.

Response of trees to soil disturbance is variable and climate, and perhaps tree species. 
Isolating effects of such traffic on individual tree growth is difficult.
We surmise that growth in thinned stands could be reduced initially where roots of residual trees are crushed or severed by heavy equipment, and later where roots encounter degraded soil conditions. Although proximity and severity of equipment traffic are important variables affecting tree response after commercial thinning, isolating effects of such traffic on individual tree growth is difficult. Growth after thinning is also strongly influenced by initial tree size, degree of release when neighboring trees are removed, and subsequent competition among residual trees and other vegetation.

Our investigations at three locations in the Coast Range of western Oregon sought to answer two questions: Did proximity to trails used by various groundbased logging vehicles affect subsequent tree growth? At two of these locations, we posed two additional questions: Did past nitrogen $(\mathrm{N})$ fertilization continue to increase growth or influence tree response to equipment traffic?

\section{Methods}

\section{Toledo South and Bone Mountain}

At these two locations, we investigated former research plantations of uniformly spaced Douglas-fir that were about 20 years old from seed (fig. 1). The sensitivity of our research design was further enhanced at Toledo South because commercial thinning systematically removed alternate rows of trees with no in-row removal. Consequently, both release and subsequent competition for residual trees were highly uniform.

The plantations were established in 1974 after clearcutting and intensive site preparation on former Georgia Pacific Corporation land in the Oregon Coast Range. The Toledo South plantation near Toledo, Oregon, is located on gently sloping topography mapped as Elsie silt loam, a fine-silty mixed, mesic Typic Haplohumult (USDA NRCS 1997). Elevation averages about $300 \mathrm{ft}$. The 50-year site index (King 1966) averages $143 \mathrm{ft}$ for this well-drained soil developing on alluvium.

Bone Mountain plantations A and B are near Coquille, Oregon, on gently sloping topography mapped as Preacher loam, a fine-loamy, mixed, mesic Typic Haplumbrept, developing on marine sediments (Haagen 1989). Elevation averages about 1,500 ft. The 50-year site index averages $127 \mathrm{ft}$.

At both locations, 1-year-old, container-grown seedlings were planted at a precise 8- x 10-ft spacing (Toledo) or 8- x 8-ft spacing (Bone Mountain A and B), 

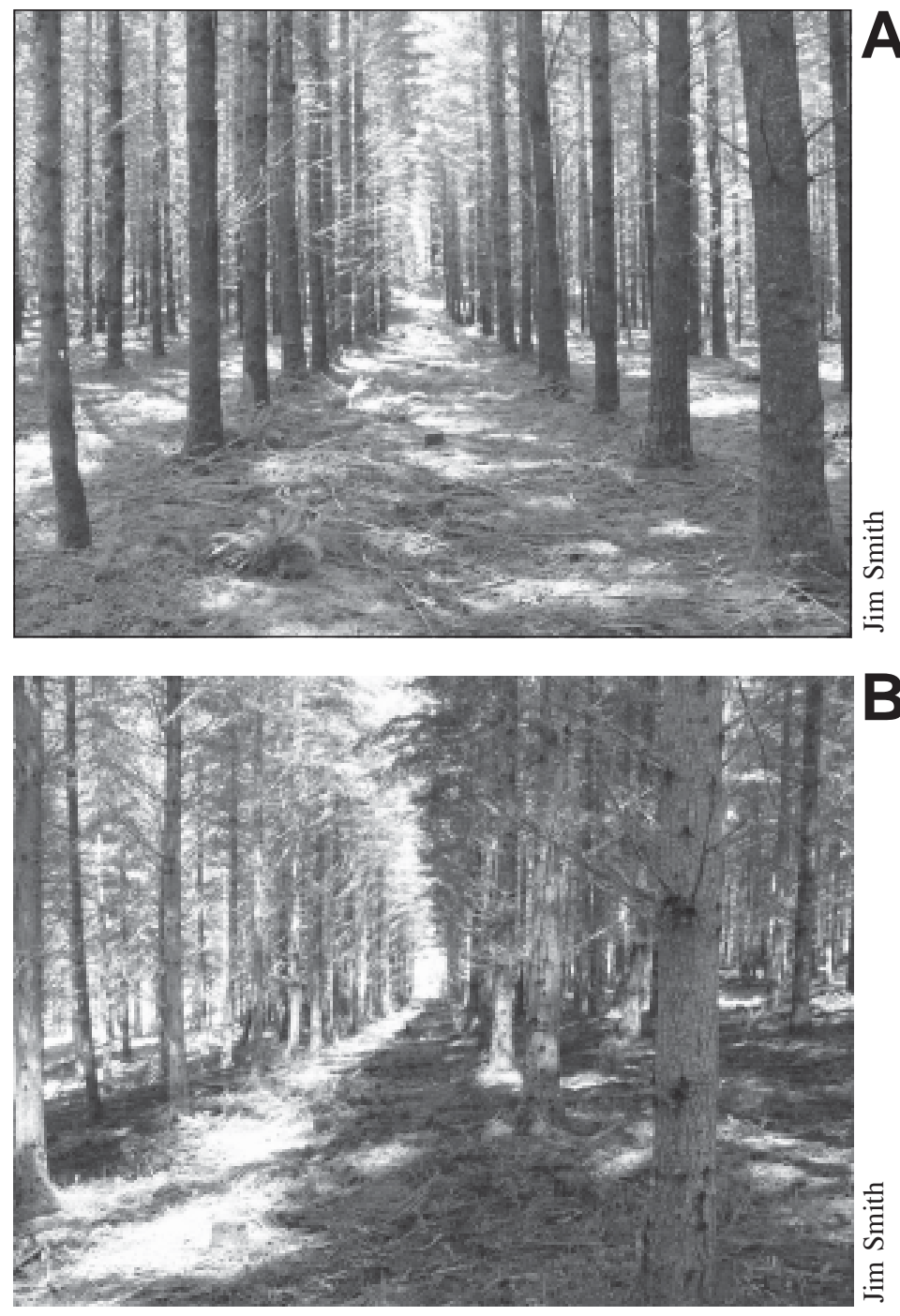

Figure 1-Typical portions of the plantation at (A) Toledo South and (B) Bone Mountain A after the 2004 growing season and 10 years after commercial thinning. Note low-cut stumps between rows and some within-row tree removal at (B).

and within 10-acre areas surrounded by an 8-ft-tall fence to exclude large animals. Seedlings were planted in blocks of 10 plots (Toledo) or 6 plots (Bone Mountain A and B). Plots were 0.243 acre (Toledo) or 0.212 acre (Bone Mountain). Although each plot contained about six randomly located seedlings from the same 30 half-sib families, these 30 families differed among Toledo South, Bone Mountain A, and Bone Mountain B. After planting, seedlings were carefully safeguarded from weeds, disease, and small animals. This protection and some replacement planting resulted in exceptionally uniformly spaced, well-stocked stands. 
The 20-year-old plantations were systematically thinned. At Toledo South, no trees were cut in the remaining evennumbered rows.

\section{Fertilization-}

After the 1989 growing season, a fertilization treatment was assigned randomly to 5 of the 10 plots at Toledo and to 3 of the 6 plots at both Bone Mountain A and B. Urea fertilizer providing $200 \mathrm{lb}$ N/acre was uniformly spread over assigned plots. Cool weather and showers in the 2 weeks after fertilization probably minimized potential loss of urea from volatilization.

\section{Thinning-}

After the 1993 growing season, the 20-year-old plantations were systematically thinned. At Toledo South, a tracked harvester (John Deere 490) and wheeled forwarder (1010 Timberjack) were used. ${ }^{l}$ Every seventh row was removed to provide routes for equipment traffic (in a direction diagonal to the original planting rows and columns). Slash was accumulated and retained on the traffic route. Centerto-center distance between these routes was about $54 \mathrm{ft}$ ( 6 rows $x 9 \mathrm{ft})$. In alternate rows between these routes, all trees were cut and removed by extending the harvester boom. No trees were cut in the remaining even-numbered rows, which included two rows beside the travel routes and one interior row (fig. 2). Thereby, stand density was reduced from about 600 trees per acre (TPA) to about 300 TPA. We suspect that this operational thinning was conducted extra carefully because the operator knew the plantation was special. Thinning occurred in April and surface soil was moist.

At Bone Mountain A and B, every fifth row of the original planting was removed to provide traffic routes for a tracked harvester (Timberjack 1270B) and rubber-tired forwarder (Timberjack 1210B, fig. 3). Although less slash was accumulated and retained at Bone Mountain A and B than at Toledo South, ruts were barely visible and less than 3 in deep. Center-to-center distance between these routes was about $32 \mathrm{ft}$ ( 4 rows $\mathrm{x} 8 \mathrm{ft}$ ). Because additional trees within the three remaining interior rows were cut and removed, tree removal within the two trailside and one interior row was not as uniform as at Toledo South (fig. 2). The original density of 680 TPA was reduced to about 260 TPA (62 percent cut). Thinning was completed in June and the surface soil was dry and dusty.

\footnotetext{
${ }^{1}$ The use of trade or firm names in the publication is for reader information and does not imply endorsement by the U.S. Department of Agriculture of any product or services.
} 


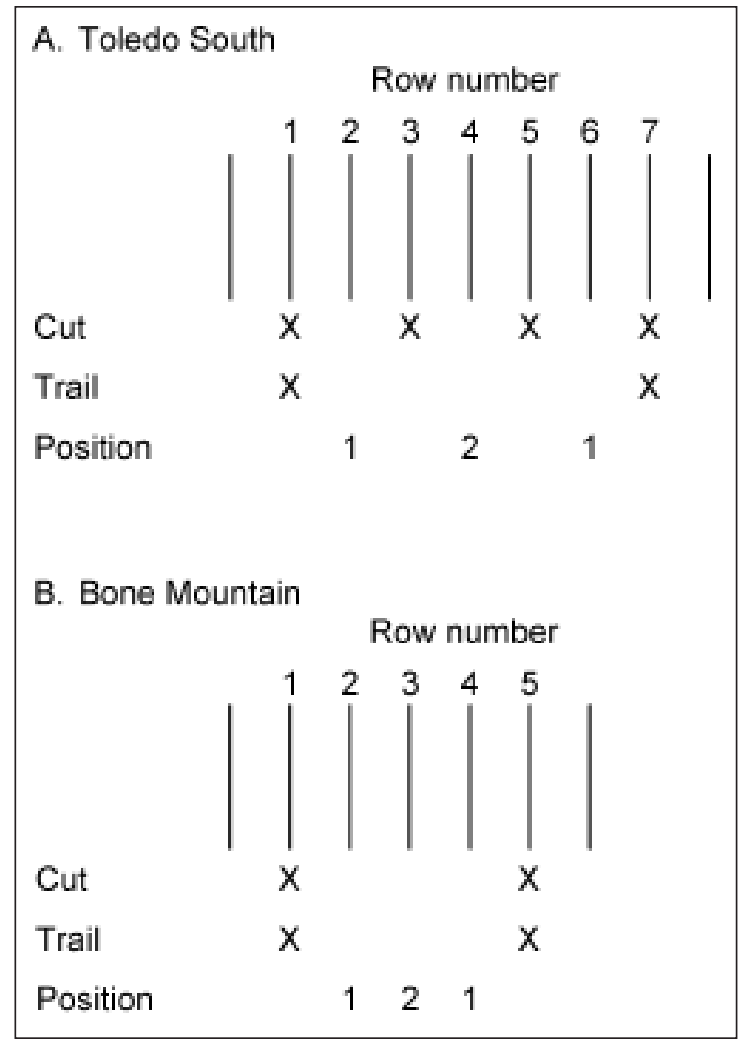

Figure 2-Pattern of commercial thinning at (A) South Tract and (B) Bone Mountain $\mathrm{A}$ and $\mathrm{B}$.

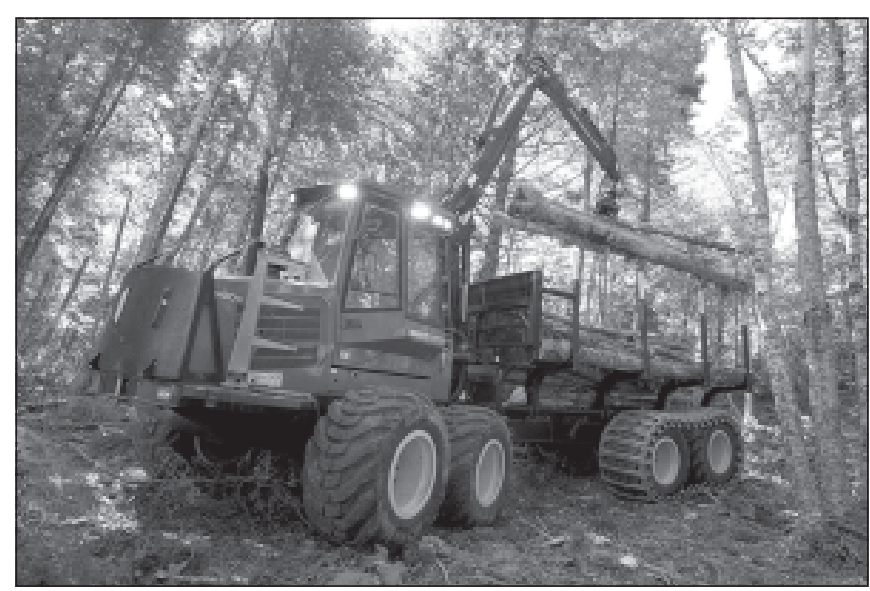

Figure 3-Rubber-tired forwarder used at Bone Mountain $\mathrm{A}$ and $\mathrm{B}$. 
Residual trees were identified in two categories: those located beside traffic routes (position 1) and those located in interior rows between traffic routes (position 2 ).

\section{Tree measurements-}

Diameter at breast height (d.b.h.) of all trees was measured periodically with a steel tape to the nearest $0.1 \mathrm{in}$. At Toledo South, d.b.h. was measured after the growing season in 1989 (before fertilization), 1993 (before commercial thinning), 1997, and 2000 (year 7 after thinning, year 11 after fertilizing, and year 27 after planting). At Bone Mountain A and B, d.b.h. was measured after the growing seasons of 1989 (before fertilization), 1993 (before thinning), and 2004 (year 11 after thinning, year 15 after fertilizing, and year 30 after planting). Trees in the interior plot of each whole plot were identified with numbered aluminum tags at breast height (b.h.) (4.5 $\mathrm{ft}$ ) and were pruned to 6-ft height to provide safe access and more reliable measurement of d.b.h. Buffer areas around interior plots contained only one row of nontagged trees.

\section{Data summary-}

After commercial thinning, residual trees were identified in two categories: those located beside traffic routes (position 1) and those located in interior rows between traffic routes (position 2). Because some within-row trees were removed at Bone Mountain A and B, residual trees in position 1 and position 2 had varying numbers of neighboring or competing trees, ranging from zero to four of the initial eight. Number of competing neighbors was tallied as a measure of residual competition. Tree diameters were examined on a plot-by-plot basis by plotting average annual d.b.h. growth after thinning against d.b.h. before thinning. One tree at Toledo was rejected as spurious. Two trees were rejected at Bone Mountain A and seven at Bone Mountain B for two reasons: spurious growth related to forking below the b.h. measurement point or excessive growth of some position 1 trees that was clearly related to excessive release and isolation. Thereafter, d.b.h. growth was converted to cross-sectional (BA) growth as the dependent variable in growth analyses.

\section{Statistical analysis-}

Effects of commercial thinning on mean BA growth per tree were estimated and compared by analysis of variance (ANOVA) (fixed-effects, SE method) using a split-plot, completely randomized design (SAS Institute, Inc. 1999). The large experimental units are plots, and the whole-plot treatments are fertilized and nonfertilized. The small experimental units are groups of trees in each plot that were either adjacent to an equipment trail (position 1) or interior (position 2). Both fertilized (whole-plot treatment) and position are fixed effects. 


\section{Noti}

The 18.5-acre study area was in a stand of 58-year-old Douglas-fir, located on U.S. Department of the Interior Bureau of Land Management land near Noti, about $10 \mathrm{mi}$ west of Eugene, Oregon. The site is in the eastern portion of the Oregon Coast Range at an elevation of about $625 \mathrm{ft}$, where a mild, temperate climate averages about 50 in of precipitation annually. Soils in the study area are derived from sedimentary rocks and are of a silty clay loam texture near the surface, with increasing clay content with depth. The surface mineral layer is highly porous, rich in organic matter, and of relatively low BD and strength. The USDA soil classification is clayey, mixed, mesic Xeric Haplohumults, primarily Jory series with a small area of Bellpine at the upper portion of the unit (Patching 1987). Slopes average 14 percent.

Our study area covers most of a 24-acre unit that averaged 206 TPA before thinning (summer 1992). Thinning reduced stand density to 70 TPA (66 percent cut) and produced harvested logs averaging 10 inches in diameter. Timber volume removed averaged $12.7 \mathrm{mbf}$ per acre Scribner scale (Hogervorst 1994).

\section{Thinning-}

Logging that began in late July was completed by late August. Hot and dry weather reduced soil moisture to less than 20 percent (weight basis) on all skid trails. Trees in skid trails were felled with a shear attachment on a crawler tractor (Case 1150C). Other trees were manually felled toward the trails (i.e., felled to lead) using chain saws. Although yarding of whole trees and logs was done primarily with a rubbertired skidder (John Deere 648D) with cable chokers, some skidding was done with a crawler tractor (Case 850D). Static, unloaded ground pressures of the three vehicles ranged from 39 to $54 \mathrm{kPa}$ (5.6 to $7.8 \mathrm{psi}$ ). Logs were skidded to roadside landings

Skid trails were spaced about $150 \mathrm{ft}$ apart, which covered about 7 percent of the study area. at the end of seven parallel, planned skid trails spaced about $150 \mathrm{ft}$ apart, which covered about 7 percent of the study area (fig. 4).

In early September 1992, four skid trails were tilled with a self-drafting, hydraulically controlled, winged subsoiler (Davis 1990) mounted on a large crawler tractor. The winged shanks are specifically designed to lift and fracture the soil, thereby providing extensive soil loosening as deep as 20 to 40 in (Andrus and Froehlich 1983). Because logging debris and other surface organic matter can impede effective tillage, trail-clearing with a brush rake was necessary in some trail locations before tillage. 


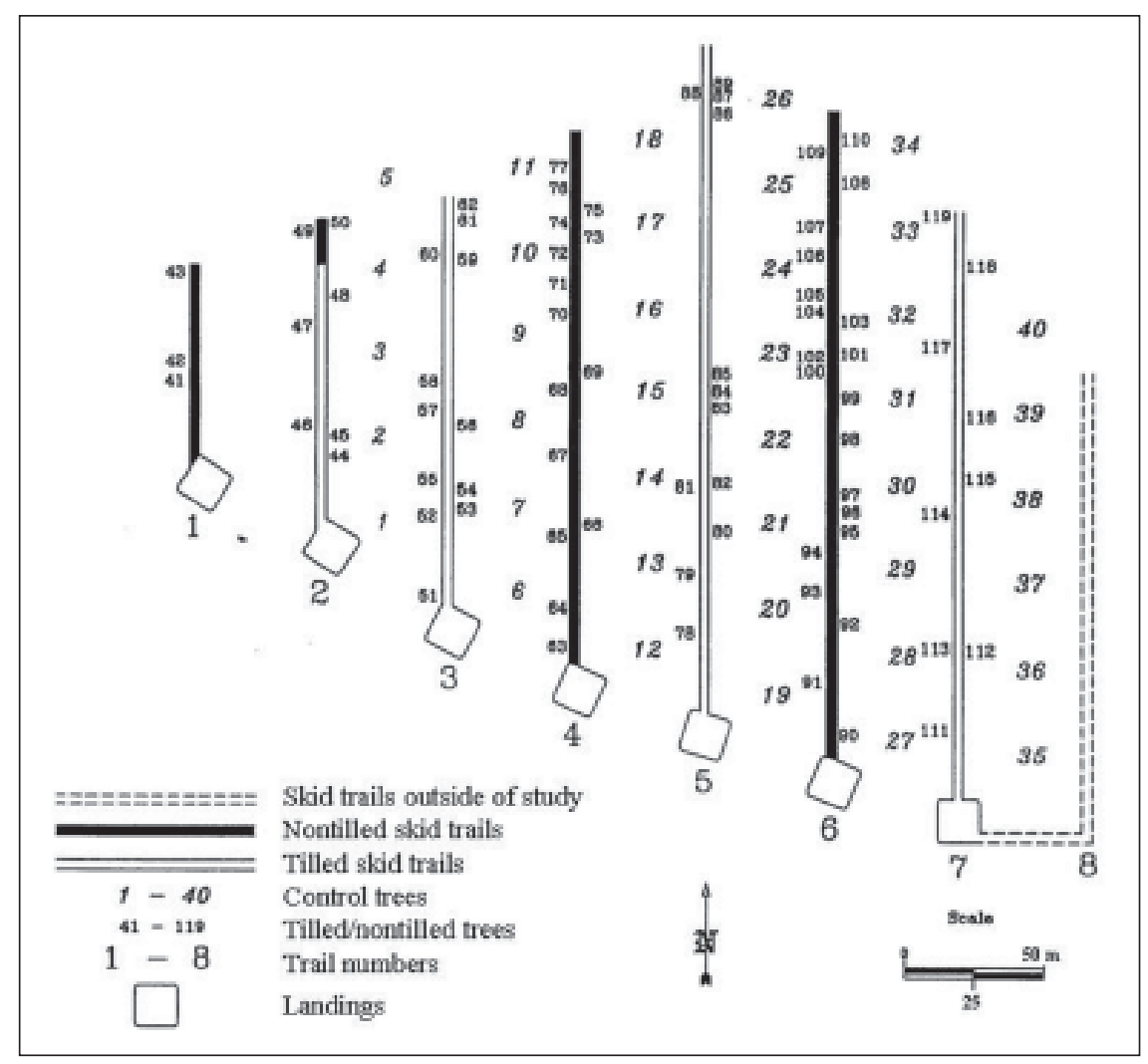

Figure 4-Sample tree locations at Noti.

\section{Tree measurements-}

Shortly after logging and tillage, a total of 119 residual trees between and near both tilled and nontilled skid trails (fig. 4) were tagged and measured for d.b.h., height, crown characteristics, and a competition index before and after thinning. Diameters and distances of all trees within a 40-ft radius of each study tree were used to calculate a d.b.h.-based competitive stress index (CSI) before and after thinning (Arney 1973).

Sampling provided about 40 trees in each of three categories relative to skid trails: tilled, nontilled, and nontrail (i.e., thinned but no trail influence). Sample trees next to tilled and nontilled trails were selected intentionally to be close enough to be influenced by the trail conditions; they averaged about 35 percent of their lateral root extent within the adjacent trail area. Earlier compaction studies (Froehlich 1979) suggested this is sufficient to impact residual tree growth significantly. Although sample trees were not chosen randomly, care was taken to select trees in each of the three "treatment" categories that were similar and representative of the thinned area as a whole. 
Because tillage resulted in noticeable damage to roots of trees adjacent to trails, a damage index was used to evaluate potential relation with observed growth responses. Measurements of the average diameter and length of severed and exposed roots were thus combined with subjective judgment to place each tree into a low, moderate, or high damage class.

\section{Soil bulk density measurements-}

Soil BD in skid trails and around residual trees was measured with nuclear densiometers shortly after logging, just after tillage (Hogervorst 1994), and after seven growing seasons (Martinez 2000). Three measurements were taken around each nontrail tree within a vertical projection of crown diameter, whereas six measurements were taken around the other trees, half of these on and half off the trail (fig. 5). Because of the extended time (7 years) between initial and final soil measurement, different densiometers were used in 1992 (Campbell Pacific Nuclear

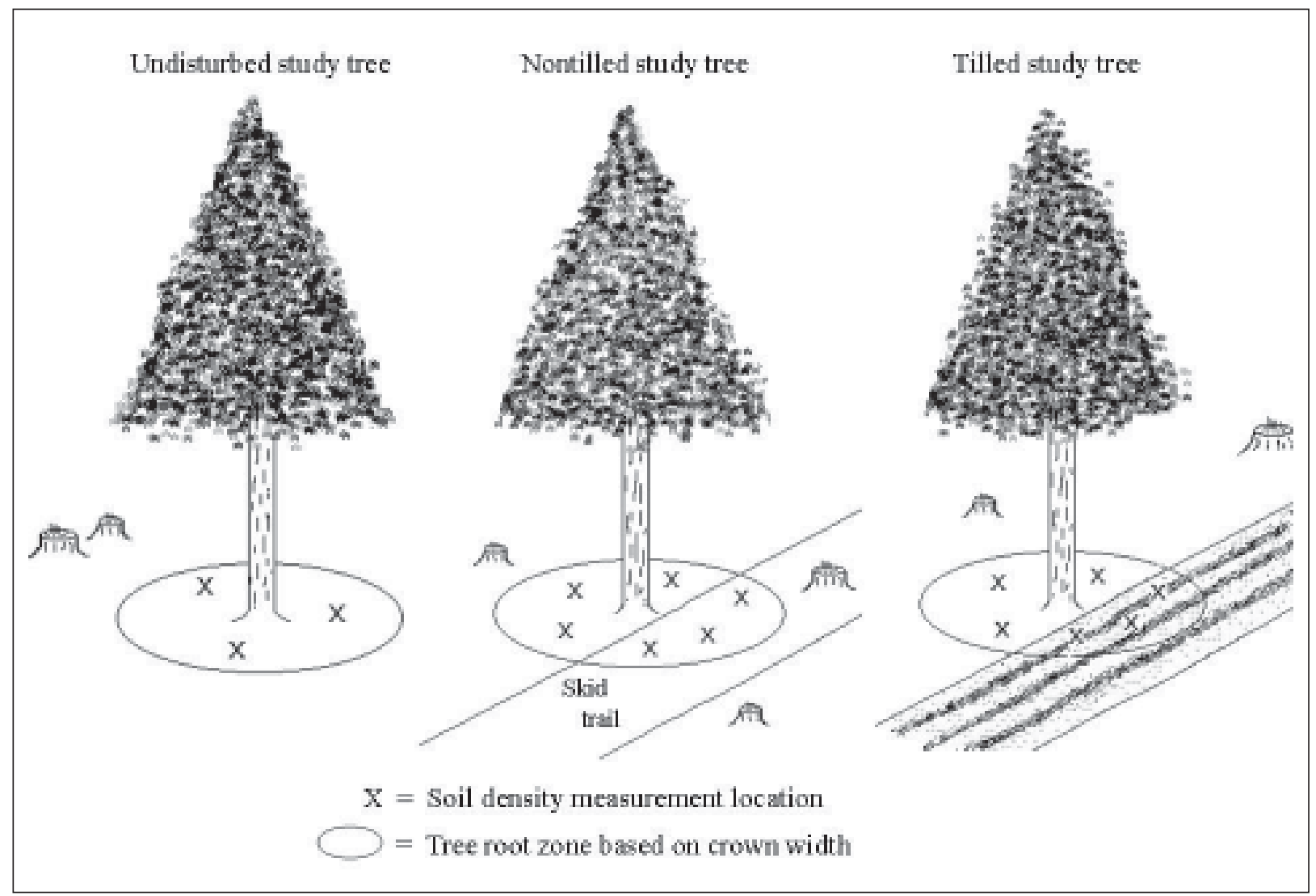

Figure 5-Pattern of soil bulk density sampling at Noti. 


\section{Trees sampling each treatment are located near spe- cific trails.}

MC-1 Stratagauge) and 1999 (Boart Longyear MC-3 Portaprobe). Although major design differences (i.e., double- vs. single-probe) preclude direct, quantitative comparisons of bulk density data from the two devices, some general contrasts or trends should be discernible.

\section{Data summary-}

Tree diameters of 1992 and 1999 were evaluated initially by plotting average annual d.b.h. growth after thinning against d.b.h. before thinning. Two trees were rejected as spurious. One tree grew much greater than the rest and the other tree showed negative growth. For remaining trees, d.b.h. was converted to cross-sectional (BA) growth as the dependent variable in growth analysis.

\section{Statistical analyses-}

Data were analyzed by analysis of covariance (ANCOVA) (SAS Institute, Inc. 1999). Note that trees sampling each treatment are located near specific trails (fig. 4). This means that trails are nested within treatments. There are four tilled trails, which contribute 3 degrees of freedom (d.f.) to error. Similarly, three nontilled trails contribute 2 d.f., and six nontrail areas between skid trails contribute 5 d.f., for a total of 10 . An alpha value of 0.10 was used to judge statistical significance.

\section{Results}

\section{Toledo South}

\section{Stand statistics before thinning-}

Before commercial thinning at Toledo South, the 10 plots averaged 600 TPA, about $190 \mathrm{ft}^{2} \mathrm{BA}$, and relative density (RD) of 68 (table 1). Thinning removed 50 percent of these trees (51 percent of initial BA), and reduced mean RD to 33. Relative density (Curtis 1982) is an index of competition that can help predict mortality losses. An RD value of 70 portends losses from overstocking. As anticipated, the rowthinning at South Tract removed and left similar TPA and BA/acre in both the fertilized and nonfertilized plots.

\section{Tree d.b.h. and sample size-}

Before thinning, d.b.h. among position 1 trees (near future trails) averaged 7.7 in on both fertilized and nonfertilized plots (table 2). Position 2 trees (located away from the parallel trails) similarly averaged 7.6 in on both fertilized and nonfertilized plots. After thinning, the number of position 1 trees (beside two trails) was nearly twice that of position 2 trees located in one interior row (table 2). 
Table 1-Mean live-stand statistics at Toledo South before and after commercial thinning in 1993

\begin{tabular}{|c|c|c|c|c|c|c|c|c|c|c|}
\hline \multirow[b]{2}{*}{ Fertilizer } & \multirow[b]{2}{*}{ Plot } & \multicolumn{3}{|c|}{ Before } & \multicolumn{3}{|c|}{ After } & \multicolumn{3}{|c|}{ Cut } \\
\hline & & Trees & $\begin{array}{c}\text { Basal } \\
\text { area }\end{array}$ & RD & Trees & $\begin{array}{c}\text { Basal } \\
\text { area }\end{array}$ & RD & Trees & $\begin{array}{c}\text { Basal } \\
\text { area }\end{array}$ & RD \\
\hline \multicolumn{2}{|l|}{ Lb N/acre } & Trees/acre & \multicolumn{2}{|c|}{$F t^{2} /$ acre } & \multicolumn{3}{|c|}{ Trees/acre $F^{2} /$ acre } & Trees/acre & $\mathrm{Ft}^{2} /$ acre & \\
\hline \multirow[t]{7}{*}{0} & 1 & 605 & 214.7 & 75 & 292 & 105.1 & 37 & 313 & 109.6 & 38 \\
\hline & 2 & 630 & 202.1 & 73 & 292 & 96.4 & 34 & 337 & 105.7 & 38 \\
\hline & 4 & 626 & 186.3 & 68 & 317 & 87.0 & 33 & 309 & 99.3 & 36 \\
\hline & 8 & 572 & 168.8 & 62 & 284 & 84.0 & 31 & 288 & 84.8 & 31 \\
\hline & 10 & 605 & 192.7 & 70 & 309 & 92.3 & 34 & 296 & 100.3 & 36 \\
\hline & Mean & 608 & 192.9 & 70 & 299 & 93.0 & 34 & 309 & 99.9 & 36 \\
\hline & Percent & - & - & & & - & - & 51 & 52.0 & 51 \\
\hline \multirow[t]{7}{*}{200} & 3 & 601 & 205.7 & 73 & 317 & 104.9 & 38 & 284 & 100.8 & 35 \\
\hline & 5 & 593 & 200.2 & 71 & 296 & 98.4 & 35 & 296 & 101.7 & 36 \\
\hline & 6 & 568 & 167.8 & 62 & 284 & 88.1 & 32 & 284 & 79.7 & 30 \\
\hline & 7 & 597 & 177.3 & 65 & 305 & 87.1 & 32 & 292 & 90.2 & 33 \\
\hline & 9 & 597 & 181.1 & 66 & 284 & 84.1 & 31 & 313 & 97.0 & 35 \\
\hline & Mean & 591 & 186.4 & 67 & 297 & 92.5 & 33 & 294 & 93.9 & 34 \\
\hline & Percent & - & - & & - & - & & 50 & 50.0 & 51 \\
\hline \multirow[t]{2}{*}{ All } & & 600 & 189.6 & 68 & 298 & 92.8 & 33 & 302 & 96.9 & 35 \\
\hline & Percent & 100 & 100 & 100 & 50 & 49 & 49 & 50 & 51 & 51 \\
\hline
\end{tabular}

$\mathrm{N}=$ nitrogen; $\mathrm{RD}=$ Relative density (Curtis 1982); $-=$ not applicable. 
Table 2-Sample size and arithmetic mean diameter at breast height (d.b.h.) at Toledo South

\begin{tabular}{|c|c|c|c|c|c|c|}
\hline \multirow[b]{2}{*}{ Fertilizer } & \multirow[b]{2}{*}{ Plot } & \multirow[b]{2}{*}{ Position $^{a}$} & \multirow[b]{2}{*}{ Sample size } & \multicolumn{3}{|c|}{ D.b.h. ${ }^{b}$} \\
\hline & & & & 1989 & 1993 & 2000 \\
\hline \multicolumn{4}{|l|}{ Lb N/acre } & \multicolumn{3}{|c|}{---- Inches ----} \\
\hline \multirow[t]{12}{*}{0} & \multirow[t]{2}{*}{1} & 1 & 27 & 7.5 & 8.4 & 10.8 \\
\hline & & 2 & 15 & 7.5 & 8.5 & 10.8 \\
\hline & \multirow[t]{2}{*}{2} & 1 & 27 & 7.0 & 7.9 & 10.1 \\
\hline & & 2 & 18 & 7.0 & 7.8 & 10.2 \\
\hline & \multirow[t]{2}{*}{4} & 1 & 26 & 6.8 & 7.6 & 10.1 \\
\hline & & 2 & 17 & 6.5 & 7.3 & 9.6 \\
\hline & \multirow[t]{2}{*}{8} & 1 & 31 & 6.2 & 7.1 & 9.5 \\
\hline & & 2 & 14 & 6.2 & 7.1 & 9.6 \\
\hline & \multirow[t]{2}{*}{10} & 1 & 30 & 6.8 & 7.7 & 10.1 \\
\hline & & 2 & 16 & 6.5 & 7.5 & 9.4 \\
\hline & \multirow[t]{2}{*}{ Mean } & 1 & 34 & 6.9 & 7.7 & 10.1 \\
\hline & & 2 & 16 & 6.7 & 7.6 & 9.9 \\
\hline \multirow[t]{12}{*}{200} & \multirow[t]{2}{*}{3} & 1 & 38 & 7.3 & 8.2 & 10.4 \\
\hline & & 2 & 9 & 7.0 & 8.0 & 10.2 \\
\hline & \multirow[t]{2}{*}{5} & 1 & 34 & 7.1 & 8.0 & 10.4 \\
\hline & & 2 & 10 & 6.9 & 7.8 & 10.1 \\
\hline & \multirow[t]{2}{*}{6} & 1 & 30 & 6.2 & 7.3 & 9.7 \\
\hline & & 2 & 15 & 6.4 & 7.6 & 10.0 \\
\hline & \multirow[t]{2}{*}{7} & 1 & 32 & 6.1 & 7.2 & 9.6 \\
\hline & & 2 & 17 & 6.2 & 7.3 & 9.6 \\
\hline & \multirow[t]{2}{*}{9} & 1 & 28 & 6.5 & 7.7 & 10.2 \\
\hline & & 2 & 15 & 6.4 & 7.5 & 9.9 \\
\hline & \multirow[t]{2}{*}{ Mean } & 1 & 32 & 6.6 & 7.7 & 10.1 \\
\hline & & 2 & 13 & 6.6 & 7.6 & 10.0 \\
\hline
\end{tabular}

$\mathrm{N}=$ nitrogen.

${ }^{a} 1$ = beside trail, 2 = no trail.

${ }^{b} 1989=$ before fertilization, 1993 = before thinning.

Position 1 and 2 trees had similar numbers of competitors.
Among the 10 plots, 303 measured trees were located in the rows beside trails and 147 were in the one noncut row midway between adjacent trails. This difference in sample size is consistent with the thinning prescription and our field observation that little or no within-row thinning had occurred. Therefore, position 1 and position 2 trees had similar numbers of competitors. Bole damage to residual trees was infrequent and of minor severity. 


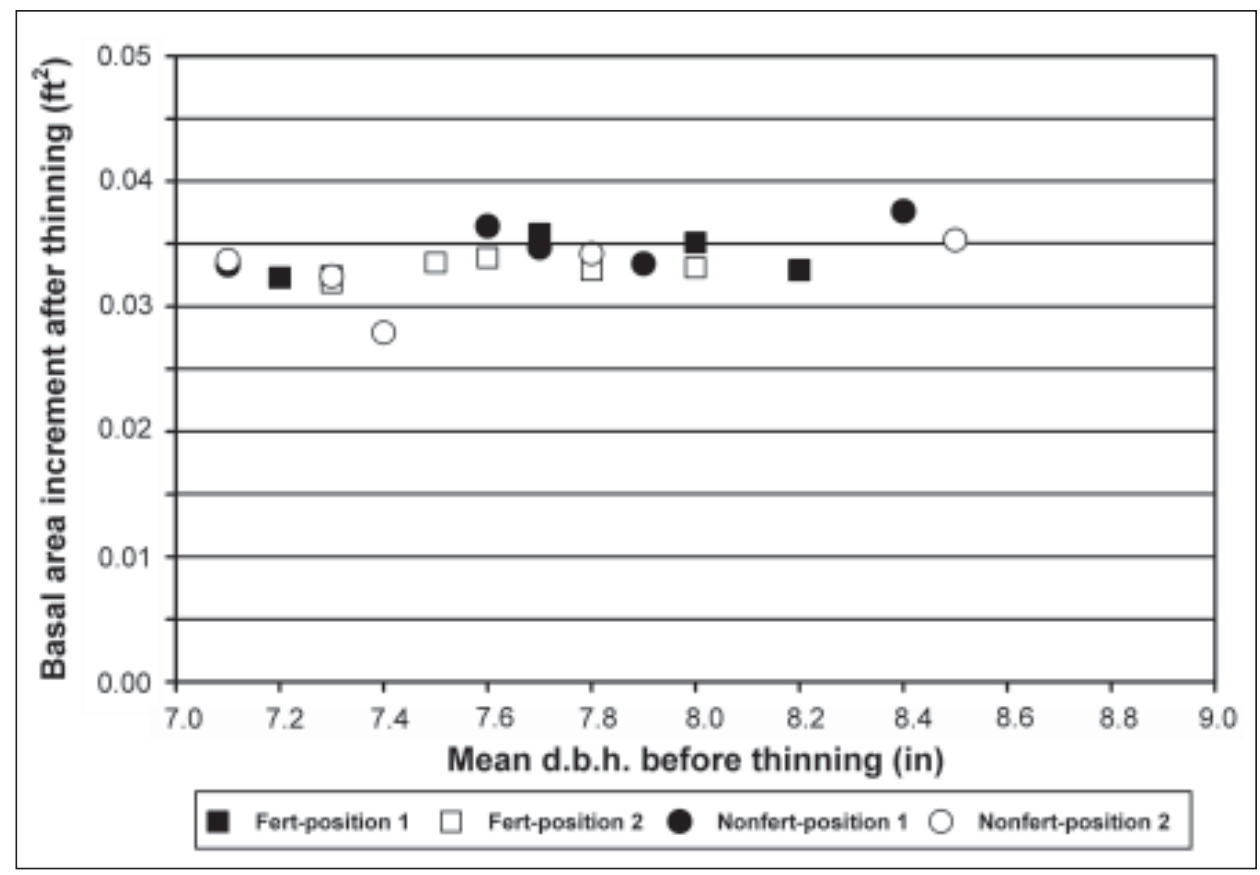

Figure 6-Mean annual basal area (BA) growth of individual trees in a 7-year period after commercial thinning at Toledo South, by position (beside equipment trail $=$ position 1 or interior $=$ position 2) and by previous fertilization treatment (fert $=200 \mathrm{lb}$ N/acre and nonfert $=0 \mathrm{lb} \mathrm{N} /$ acre), related to mean diameter at breast height (d.b.h.) before thinning.

\section{Basal area growth after thinning-}

Preliminary plotting of mean annual BA growth per tree in the 7 years after thinning suggested that growth was related to mean d.b.h. at thinning (fig. 6). Each plotting point (a specified plot and position) is the mean of 9 to 34 trees (table 2). Because before-thinning growth was influenced by fertilization, we did not use covariance analysis to test differences among adjusted treatment means. To do so would have removed some of the effects of the fertilizer treatments.

Mean BA growth per tree was similar on previously fertilized and nonfertilized plots ( $\mathrm{p}=0.60$, table 3 ). Note that in the first 4 years after fertilization (and before thinning), fertilized plots at this location averaged about 11 percent greater BA growth per acre than nonfertilized $(p=0.07$, Miller and others 2001). Because the $\mathrm{P} \times \mathrm{F}$ interaction was statistically nonsignificant $(\mathrm{p}=0.29$, table 3$)$, we infer that tree response to trails was independent of earlier fertilization. Trees next to trails averaged about 3 percent faster growth in cross-sectional area at b.h. than trees located farthest from the trails $(\mathrm{p}=0.09)$.

Tree response to trails was independent of earlier fertilization. 
Table 3-Statistical significance of prior fertilization, proximity to equipment trails, and their interaction effect on 7-year mean annual basal area (BA) growth per tree after commercial thinning at Toledo South

\begin{tabular}{lccc}
\hline Factor & D.f. & F-value & P \\
\hline Main plots: & & 0.21 & \\
$\quad$ Fertilizer (F) & 1 & 0.30 & 0.601 \\
$\quad$ Plots within F (error 1) & 8 & - & - \\
Split-plots: & & & .088 \\
Position (P) & 1 & 3.79 & -290 \\
P x F & 1 & 1.28 & - \\
$\quad$ Error & 8 & - & \\
Total & 19 & &
\end{tabular}

Adjusted treatment means and 90-percent confidence interval

\begin{tabular}{lccc} 
Fertilizer: & \multicolumn{2}{c}{$\begin{array}{c}\text { Mean basal area growth } \\
\left(\mathrm{ft}^{2} / \text { year }\right)\end{array}$} & $\begin{array}{c}\text { Relative } \\
\text { percentage }\end{array}$ \\
\cline { 2 - 4 } $0 \mathrm{~N}$ & 0.0339 & $(0.0327-0.0351)$ & 100 \\
$200 \mathrm{~N}$ & 0.0334 & $(0.0322-0.0346)$ & $99^{a}$ \\
Position: & & & \\
1 (Beside trail) & 0.0344 & $(0.0333-0.0355)$ & 100 \\
2 (Mid row) & 0.0329 & $(0.0317-0.0340)$ & 97 \\
\hline
\end{tabular}

$\mathrm{N}=$ nitrogen; $200 \mathrm{~N}=200 \mathrm{lb} \mathrm{N} / \mathrm{acre} ;-=$ not applicable.

${ }^{a}$ In years 1-4 after fertilization, response in gross BA per acre to 200 pounds nitrogen per acre averaged 11 percent $(\mathrm{p}=0.07)$ or 6.3 percent, if adjusted for difference in prefertilization growth $(\mathrm{p}=0.25)$ (Miller and others 2001).

In both plantations, after-thinning growing stock averaged slightly greater among fertilized plots.

\section{Bone Mountain A and B}

\section{Stand statistics before and after thinning-}

Before commercial thinning, the six plots in Bone Mountain A averaged 678 TPA, about $153 \mathrm{ft}^{2} \mathrm{BA}$ per acre, and RD 61 (table 4); those at Bone Mountain B averaged 677 TPA, about $164 \mathrm{ft}^{2} \mathrm{BA}$, and RD 64 (table 5). At Bone Mountain A, thinning removed 60 percent of the trees, 56 percent of the initial BA, and reduced RD to 26 . Thinning at Bone Mountain B, was slightly heavier, removing 62 percent of the trees, 60 percent of the initial BA and also reducing RD to 26.

At both Bone Mountain A and B, previously fertilized plots had similar livestand statistics before thinning. Percentage cut (TPA, BA, RD) averaged slightly heavier among fertilized plots at Bone Mountain A, and slightly lighter at Bone Mountain B. In both plantations, after-thinning growing stock averaged slightly greater among fertilized plots (tables 4 and 5). Slightly greater growing stock could 
Table 4-Mean live-stand statistics at Bone Mountain A before and after commercial thinning in 1994

\begin{tabular}{|c|c|c|c|c|c|c|c|c|c|c|}
\hline \multirow[b]{2}{*}{ Fertilizer } & \multirow[b]{2}{*}{ Plot } & \multicolumn{3}{|c|}{ Before } & \multicolumn{3}{|c|}{ After } & \multicolumn{3}{|c|}{ Cut } \\
\hline & & Stems & $\begin{array}{c}\text { Basal } \\
\text { area }\end{array}$ & RD & Stems & $\begin{array}{c}\text { Basal } \\
\text { area }\end{array}$ & RD & Stems & $\begin{array}{c}\text { Basal } \\
\text { area }\end{array}$ & RD \\
\hline Lb N/acre & & Trees/acre & $F t^{2} /$ acre & & Trees/acre & $F t^{2} /$ acre & & Trees/acre & $F t^{2} /$ acre & \\
\hline \multirow[t]{5}{*}{0} & 1 & 693 & 158.1 & 61 & 302 & 75.0 & 29 & 392 & 83.1 & 33 \\
\hline & 2 & 670 & 145.8 & 58 & 288 & 71.1 & 27 & 382 & 74.7 & 31 \\
\hline & 6 & 660 & 157.3 & 61 & 255 & 66.7 & 25 & 406 & 90.6 & 36 \\
\hline & Mean & 674 & 153.7 & 60 & 282 & 70.9 & 27 & 393 & 82.8 & 33 \\
\hline & Percent & - & - & & - & - & & 58 & 54.0 & 55 \\
\hline \multirow[t]{5}{*}{200} & 3 & 670 & 157.8 & 62 & 250 & 63.9 & 24 & 420 & 93.9 & 37 \\
\hline & 4 & 684 & 151.1 & 60 & 259 & 63.7 & 25 & 425 & 87.4 & 35 \\
\hline & 5 & 689 & 149.9 & 60 & 259 & 63.4 & 24 & 429 & 86.5 & 35 \\
\hline & Mean & 681 & 152.9 & 61 & 256 & 63.7 & 24 & 425 & 89.3 & 36 \\
\hline & Percent & - & - & & - & - & & 620 & 60.0 & 59 \\
\hline \multirow[t]{2}{*}{ All } & & 678 & 153.3 & 61 & 269 & 67.3 & 26 & 409 & 86.0 & 35 \\
\hline & Percent & 100 & 100 & 100 & 40 & 44 & 43 & 60 & 56 & 57 \\
\hline
\end{tabular}

$\mathrm{N}=$ nitrogen; $\mathrm{RD}=$ relative density (see Curtis 1982 ); $-=$ not applicable.

Table 5-Mean live-stand statistics at Bone Mountain B before and after commercial thinning in 1994

\begin{tabular}{|c|c|c|c|c|c|c|c|c|c|c|}
\hline \multirow[b]{2}{*}{ Fertilizer } & \multirow[b]{2}{*}{ Plot } & \multicolumn{3}{|c|}{ Before } & \multicolumn{3}{|c|}{ After } & \multicolumn{3}{|c|}{ Cut } \\
\hline & & Stems & $\begin{array}{c}\text { Basal } \\
\text { area }\end{array}$ & RD & Stems & $\begin{array}{c}\text { Basal } \\
\text { area }\end{array}$ & RD & Stems & $\begin{array}{c}\text { Basal } \\
\text { area }\end{array}$ & RD \\
\hline Lb N/acre & & Trees/acre & $F t^{2} /$ acre & & Trees/acre & $F t^{2} /$ acre & & Trees/acre & $F t^{2} /$ acre & \\
\hline \multirow[t]{5}{*}{0} & 3 & 670 & 164.4 & 63 & 250 & 67.6 & 25 & 420 & 96.8 & 38 \\
\hline & 4 & 675 & 161.7 & 63 & 241 & 61.7 & 24 & 434 & 100.0 & 39 \\
\hline & 5 & 689 & 171.2 & 66 & 245 & 69.2 & 26 & 443 & 102.0 & 40 \\
\hline & Mean & 678 & 165.8 & 64 & 245 & 66.2 & 25 & 432 & 99.6 & 39 \\
\hline & Percent & - & - & & - & - & & 64 & 60.0 & 61 \\
\hline \multirow[t]{5}{*}{200} & 1 & 675 & 151.0 & 60 & 274 & 59.7 & 24 & 401 & 91.2 & 36 \\
\hline & 2 & 675 & 161.1 & 63 & 278 & 71.8 & 27 & 396 & 89.3 & 35 \\
\hline & 6 & 679 & 172.4 & 66 & 255 & 65.8 & 25 & 425 & 103.6 & 40 \\
\hline & Mean & 676 & 161.5 & 63 & 269 & 65.8 & 26 & 407 & 94.7 & 37 \\
\hline & Percent & - & - & & - & - & & 60 & 59.0 & 59 \\
\hline \multirow[t]{2}{*}{ All } & & 677 & 163.6 & 64 & 257 & 66.0 & 26 & 420 & 97.2 & 38 \\
\hline & Percent & 100 & 100 & 100 & 38 & 40 & 41 & 62 & 60.0 & 59 \\
\hline
\end{tabular}

$\mathrm{N}=$ nitrogen; $\mathrm{RD}=$ relative density (see Curtis 1982 ); $-=$ not applicable. 
At both plantations, the smaller number of residual trees in position 1 indicates greater within-row release. reduce after-thinning BA growth per tree, but increase subsequent BA growth per acre among fertilized plots compared to nonfertilized.

Tree d.b.h. and sample size-

After commercial thinning in 1993, d.b.h. at Bone Mountain A for position 1 and 2 trees averaged about 6.8 in for both fertilized and unfertilized plots (table 6). At Bone Mountain B, d.b.h. averaged 6.6 in for position 1 and 6.8 in for position 2; mean d.b.h. in both positions was slightly smaller in fertilized plots (table 7).

Although removal of every fifth row left two position 1 rows for each position 2 row (a 2:1 ratio), sample size at Bone Mountain A totaled 101 trees in position 1 and 127 in position 2. At Bone Mountain B, totals were 103 and 115 trees for positions 1 and 2, respectively. At both plantations, the smaller number of residual trees in position 1 indicates greater within-row release.

Table 6-Sample size after thinning and arithmetic mean diameter at breast height (d.b.h.) by plot position and year at Bone Mountain A

\begin{tabular}{|c|c|c|c|c|c|c|}
\hline \multirow[b]{2}{*}{ Fertilizer } & \multirow[b]{2}{*}{ Plot } & \multirow[b]{2}{*}{ Position $^{a}$} & \multirow[b]{2}{*}{ Sample size } & \multicolumn{3}{|c|}{ D.b.h. } \\
\hline & & & & 1989 & 1993 & 2004 \\
\hline \multicolumn{4}{|l|}{ Lb N/acre } & \multicolumn{3}{|c|}{---- Inches ----} \\
\hline \multirow[t]{8}{*}{0} & 1 & 1 & 18 & 5.3 & 6.8 & 10.7 \\
\hline & & 2 & 21 & 5.1 & 6.5 & 10.0 \\
\hline & 2 & 1 & 19 & 5.1 & 6.6 & 10.4 \\
\hline & & 2 & 20 & 5.4 & 6.9 & 10.5 \\
\hline & 6 & 1 & 15 & 5.5 & 7.0 & 11.3 \\
\hline & & 2 & 25 & 5.4 & 6.8 & 10.3 \\
\hline & Mean & 1 & 17 & 5.3 & 6.8 & 10.8 \\
\hline & & 2 & 22 & 5.3 & 6.7 & 10.3 \\
\hline \multirow[t]{8}{*}{200} & 3 & 1 & 18 & 5.2 & 7.0 & 11.5 \\
\hline & & 2 & 17 & 5.1 & 6.8 & 10.6 \\
\hline & 4 & 1 & 18 & 5.2 & 6.8 & 11.1 \\
\hline & & 2 & 20 & 5.1 & 6.9 & 10.7 \\
\hline & 5 & 1 & 13 & 4.9 & 6.5 & 10.9 \\
\hline & & 2 & 24 & 5.1 & 6.8 & 10.6 \\
\hline & Mean & 1 & 16 & 5.1 & 6.8 & 11.2 \\
\hline & & 2 & 20 & 5.1 & 6.8 & 10.6 \\
\hline \multirow[t]{2}{*}{ All } & All & 1 & 17 & 5.2 & 6.8 & 11.0 \\
\hline & & 2 & 21 & 5.2 & 6.8 & 10.5 \\
\hline
\end{tabular}


Table 7-Sample size after thinning and arithmetic mean diameter at breast height (d.b.h.) by plot position and year at Bone Mountain B

\begin{tabular}{|c|c|c|c|c|c|c|}
\hline \multirow[b]{2}{*}{ Fertilizer } & \multirow[b]{2}{*}{ Plot } & \multirow[b]{2}{*}{ Position $^{a}$} & \multirow[b]{2}{*}{ Sample size } & \multicolumn{3}{|c|}{ D.b.h. } \\
\hline & & & & 1989 & 1993 & 2004 \\
\hline \multicolumn{4}{|l|}{ Lb N/acre } & \multicolumn{3}{|c|}{---- Inches ----} \\
\hline \multirow[t]{8}{*}{0} & 3 & 1 & 20 & 5.5 & 6.8 & 10.7 \\
\hline & & 2 & 20 & 5.4 & 6.8 & 10.2 \\
\hline & 4 & 1 & 20 & 5.5 & 6.8 & 10.8 \\
\hline & & 2 & 19 & 5.4 & 6.6 & 9.9 \\
\hline & 5 & 1 & 14 & 5.6 & 6.8 & 11.1 \\
\hline & & 2 & 17 & 5.9 & 7.4 & 11.1 \\
\hline & Mean & 1 & 18 & 5.5 & 6.8 & 10.9 \\
\hline & & 2 & 19 & 5.6 & 6.9 & 10.4 \\
\hline \multirow[t]{8}{*}{200} & 1 & 1 & 18 & 4.6 & 6.1 & 10.0 \\
\hline & & 2 & 20 & 4.6 & 6.1 & 9.8 \\
\hline & 2 & 1 & 20 & 5.0 & 6.5 & 10.4 \\
\hline & & 2 & 19 & 5.5 & 7.1 & 10.7 \\
\hline & 6 & 1 & 11 & 5.2 & 6.7 & 10.9 \\
\hline & & 2 & 20 & 5.3 & 6.8 & 10.4 \\
\hline & Mean & 1 & 16 & 4.9 & 6.4 & 10.4 \\
\hline & & 2 & 20 & 5.1 & 6.7 & 10.3 \\
\hline \multirow[t]{2}{*}{ All } & All & 1 & 17 & 5.2 & 6.6 & 10.7 \\
\hline & & 2 & 19 & 5.4 & 6.8 & 10.4 \\
\hline
\end{tabular}

$\mathrm{N}=$ nitrogen.

${ }^{a} 1=$ beside trail, $2=$ no trail.

For the six plots at Bone Mountain A, average number of residual competitors for position 1 trees ranged from 1.6 to 2.2, but for position 2 trees ranged from 3.0 to 4.0. Corresponding numbers at Bone Mountain B were 1.5 to 2.1 for position 1 , and 3.2 to 3.7 for position 2. Because the two positions clearly have distinct, nonoverlapping mean numbers of competitors, no valid adjustment for different tree numbers by covariance analysis is possible.

\section{Basal area growth after thinning-}

Average BA growth per tree in the 11 years after thinning was consistently greater for position 1 trees at both locations (fig. 7). Based on ANOVA, the P x F interaction for both Bone Mountain A and B was statistically nonsignificant, indicating that tree growth response to trail position was independent of the earlier fertilizer treatment (tables 8 and 9). Position 1 trees averaged greater growth than position 2 trees

For both Bone Mountain $A$ and $B$, tree growth response to trail position was independent of the earlier fertilizer treatment. at both Bone Mountain A and B, 14 and 11 percent, respectively. Greater growth at 


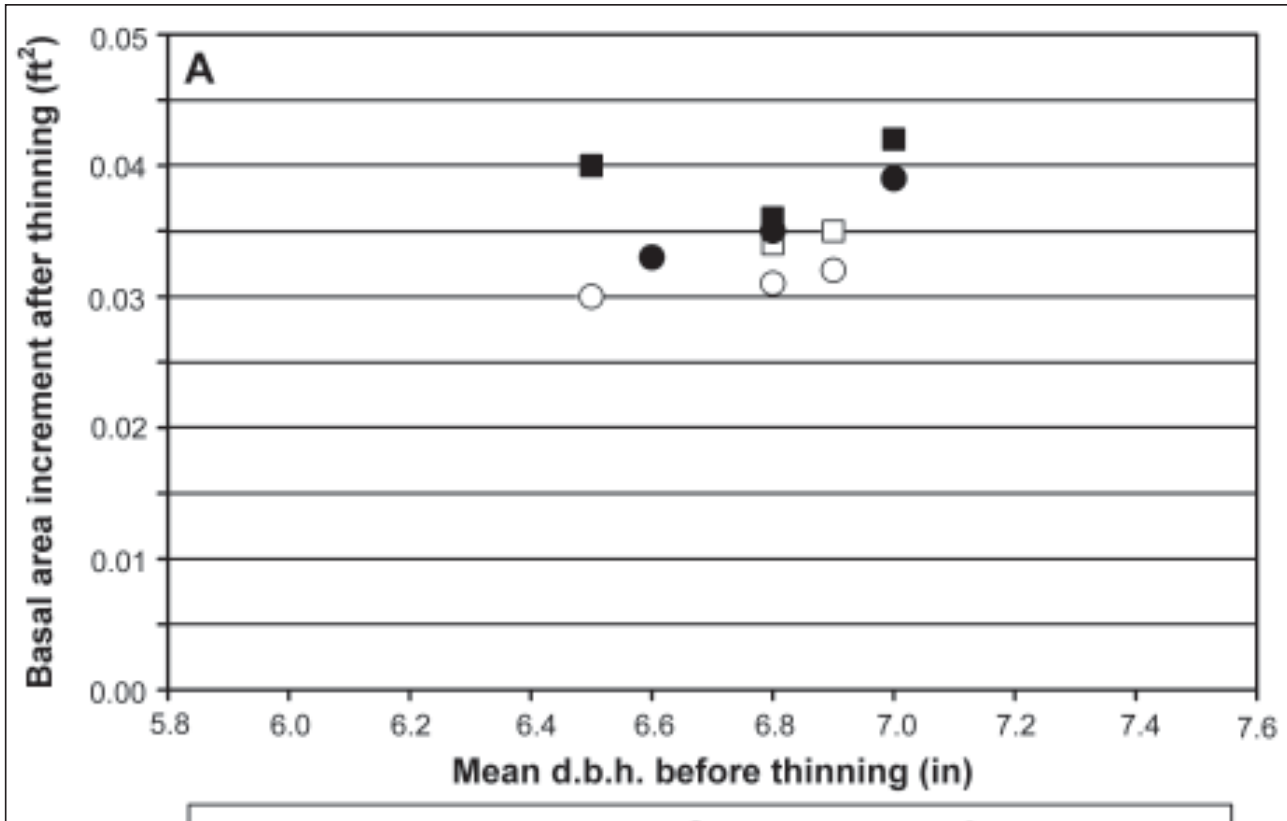

Fert-position 1

Fert-position 2

Nonfert-position $1 \bigcirc$ Nonfert-position 2

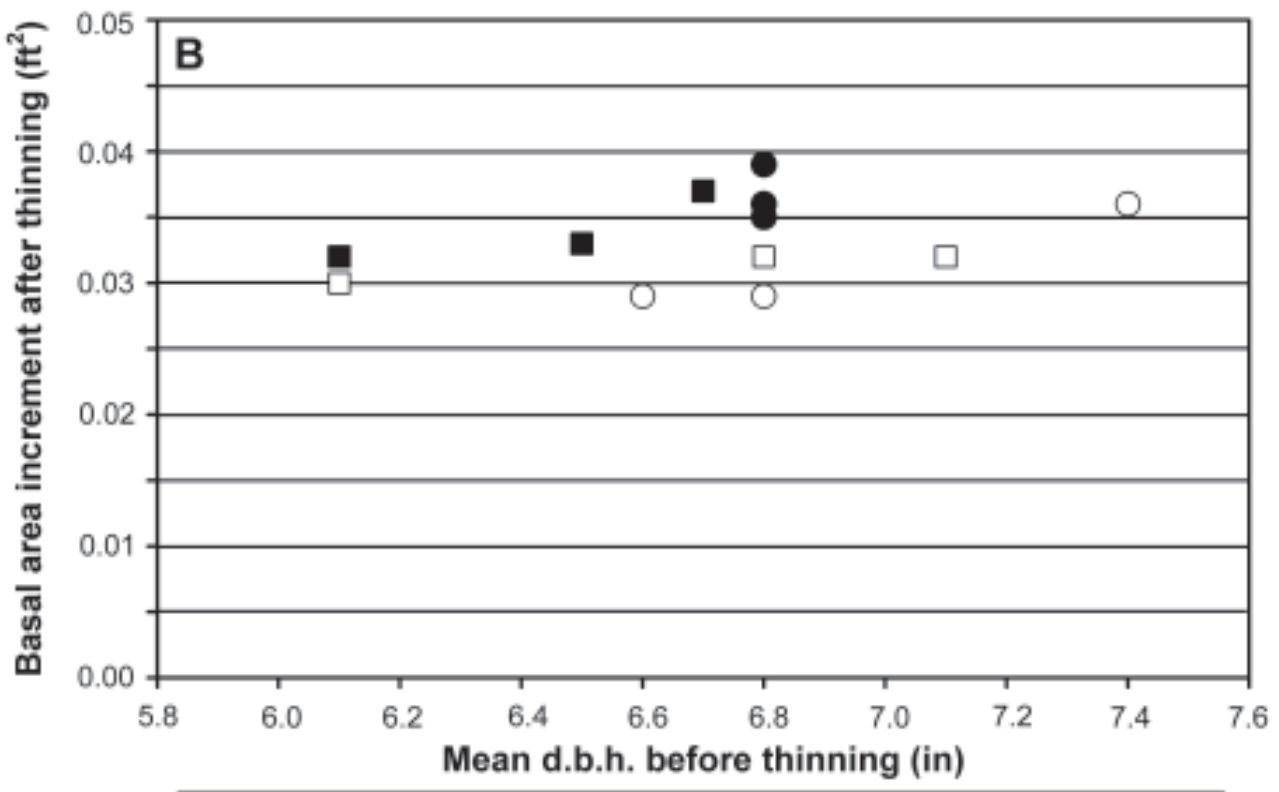

Fert-position $1 \square$ Fert-position $2 \bigcirc$ Nonfert-position $1 \bigcirc$ Nonfert-position 2

Figure 7-Mean annual basal area (BA) growth of individual trees in an 11-year period after commercial thinning, by position (beside equipment trail $=$ position 1 or interior $=$ position 2 ) and previous fertilization treatment (fert $=200 \mathrm{lb}$ N/acre and nonfert $=$ control), related to mean diameter at breast height (d.b.h.). $\mathrm{A}=$ Bone Mountain A; B = Bone Mountain B. 
Table 8-Statistical significance of prior fertilization, proximity to equipment trails, and their interaction effect on 7-year mean annual basal area growth per tree after commercial thinning at Bone Mountain A

\begin{tabular}{|c|c|c|c|}
\hline Factor & D.f. & F-value & $\mathbf{P}$ \\
\hline \multicolumn{4}{|l|}{ Main plots: } \\
\hline Fertilizer $(\mathrm{F})$ & 1 & 7.78 & 0.049 \\
\hline Plots with F (error 1) & 4 & - & - \\
\hline \multicolumn{4}{|l|}{ Split-plots: } \\
\hline Position (P) & 1 & 14.13 & .020 \\
\hline $\mathrm{P} \times \mathrm{F}$ & 1 & 0.13 & .734 \\
\hline Error 2 & 4 & - & - \\
\hline Total & 11 & & \\
\hline \multicolumn{4}{|c|}{ Treatment means and 90-percent confidence interval } \\
\hline Fertilizer: & Annual & $\begin{array}{l}\text { basal area growth } \\
\left(\mathrm{ft}^{2} / \text { year }\right)\end{array}$ & $\begin{array}{l}\text { Relative } \\
\text { percentage }\end{array}$ \\
\hline $0 \mathrm{~N}$ & 0.0333 & $(0.0313-0.0354)$ & 100 \\
\hline $200 \mathrm{~N}$ & .0372 & $(0.0351-0.0392)$ & 112 \\
\hline \multicolumn{4}{|l|}{ Position: } \\
\hline 1 (Beside trail) & .0378 & $(0.0358-0.0399)$ & 100 \\
\hline 2 (Mid row) & .0327 & $(0.0306-0.0347)$ & 86 \\
\hline
\end{tabular}

$\mathrm{N}=$ nitrogen; $200 \mathrm{~N}=200 \mathrm{lb} \mathrm{N} / \mathrm{acre} ;-=$ not applicable.

Table 9-Statistical significance of prior fertilization, proximity to equipment trails, and their interaction effect on 11-year mean annual basal area growth per tree after commercial thinning at Bone Mountain B

\begin{tabular}{|c|c|c|c|}
\hline Factor & D.f. & F-value & $\mathbf{P}$ \\
\hline \multicolumn{4}{|l|}{ Main plots: } \\
\hline Fertilizer $(\mathrm{F})$ & 1 & 0.43 & 0.547 \\
\hline Plots within F (error 1) & 4 & - & - \\
\hline \multicolumn{4}{|l|}{ Split-plots: } \\
\hline Position $(\mathrm{P})$ & 1 & 20.15 & .009 \\
\hline $\mathrm{P} \times \mathrm{F}$ & 1 & 2.46 & .192 \\
\hline Error 2 & 4 & - & - \\
\hline Total & 11 & & \\
\hline \multicolumn{4}{|c|}{ Treatment means and 90-percent confidence interval } \\
\hline Fertilizer: & Annual & $\begin{array}{l}\text { basal area growth } \\
\left(\mathrm{ft}^{2} / \text { year) }\right.\end{array}$ & $\begin{array}{c}\text { Relative } \\
\text { percentage }\end{array}$ \\
\hline $0 \mathrm{~N}$ & 0.0340 & $(0.0309-0.0371)$ & 100 \\
\hline $200 \mathrm{~N}$ & 0.0327 & $(0.0296-0.0357)$ & 96 \\
\hline \multicolumn{4}{|l|}{ Position: } \\
\hline 1 (Beside trail) & 0.0353 & $(0.0330-0.0377)$ & 100 \\
\hline 2 (Mid row) & 0.0313 & $(0.0290-0.0337)$ & 89 \\
\hline
\end{tabular}

$\mathrm{N}=$ nitrogen; $200 \mathrm{~N}=200 \mathrm{lb} \mathrm{N} / \mathrm{acre} ;-=$ not applicable. 


\section{Greater growth of position 1 trees relates to fewer competitors.}

b.h. by position 1 trees at both Bone Mountain A and B, however, is at least partially explained by greater release, hence fewer competitors around position 1 trees. Clearly, inferences about position are confounded by differing competition from neighboring trees. To some nonmeasureable extent, greater growth of position 1 trees in both plantations relates to fewer competitors near position 1 trees.

Residual effects of the earlier fertilizer treatment remained significant at Bone Mountain A (12-percent increase over control), $(\mathrm{p}=0.05$, table 8), but was not significant at Bone Mountain B (4 percent less than control $p=0.55$, table 9). Note that in the first 4 years after fertilization (and before thinning), response at Bone Mountain A also was greater than that at B. Fertilized plots at Bone Mountain A initially averaged 12.6 percent greater BA growth per acre than nonfertilized $(\mathrm{p}=$ $0.01)$ and those at Bone Mountain B initially averaged 9.2 percent more $(\mathrm{p}=0.07$, Miller and others 2001). Inferences about continuing response to past fertilization at Bone Mountain A and B, but not Toledo South, may be confounded by differences in numbers of cut and residual trees (table 4). At Bone Mountain A, fertilized plots averaged 256 TPA residual versus 282 on nonfertilized plots. This suggests that faster mean growth by fertilized trees at this location could in part, be explained by wider spacing. Conversely at Bone Mountain B, fertilized plots averaged 269 TPA residual versus 245 TPA on nonfertilized. Thus, absence of continuing per-tree response of fertilized trees at Bone Mountain B could be explained by closer spacing than on nonfertilized plots.

Noti

\section{Stand statistics before thinning-}

Before thinning in summer 1992, the nearly pure Douglas-fir stand at Noti averaged 58 years old. Small numbers of similar age western hemlock contributed to stand density that averaged 206 TPA. Thinning reduced stand density to 70 TPA (66 percent cut).

\section{Soil density-}

Bulk density near nontrail trees averaged $0.89,0.98$, and $1.05 \mathrm{Mg} / \mathrm{m}^{3}$, near the 4-, 8-, and 12-in depth, respectively. Shortly after logging, soil BD at the 4- and 8-in depths in nontilled skid trails averaged 18 and 11 percent greater, respectively, than near nontrail trees. At the 12-in depth, skid trails averaged slightly less density (3 percent). Shortly after tillage, BD in tilled trails averaged 6 percent greater than near nontrail trees at the 6-in depth, but 2 and 4 percent less dense at 8- and 12-in depths, respectively. Although tillage loosened the soil, roots of many adjacent sample trees were damaged. 
Seven years after logging, average soil BDs at the 0- to-10-in depth were similar among several sampling positions (fig. 8). Means did not differ significantly. In nontilled trails, densities averaged about 4 percent greater than in tilled trails, where BD averaged only 1 percent greater than nontrail areas (statistical tests not shown). Tillage with the winged subsoiler appeared to reduce soil BD slightly, both immediately after logging and 7 years later. Because of differing densiometers and depths of sampling, however, we have no reliable evidence for natural recovery in the nontilled trails 7 years after logging.

Because of different methods, we have no reliable evidence for natural recovery in the nontilled trails 7 years after logging.

\section{Basal area growth after thinning-}

Analyses of tree-growth relations were based on the average BA growth for study trees associated with each trail treatment. As tabulated, number of subsample trees was similar among treatments, but tilled trees had the largest average d.b.h. both before and 7 years after thinning:

\begin{tabular}{lccr} 
& & \multicolumn{2}{c}{ D.b.h. } \\
\cline { 3 - 4 } Treatment & Sample size & Before & After \\
\hline & & --- Inches --- \\
No trail & 39 & 15.3 & 16.6 \\
Nontilled & 41 & 15.4 & 16.9 \\
Tilled & 37 & 16.7 & 18.0
\end{tabular}

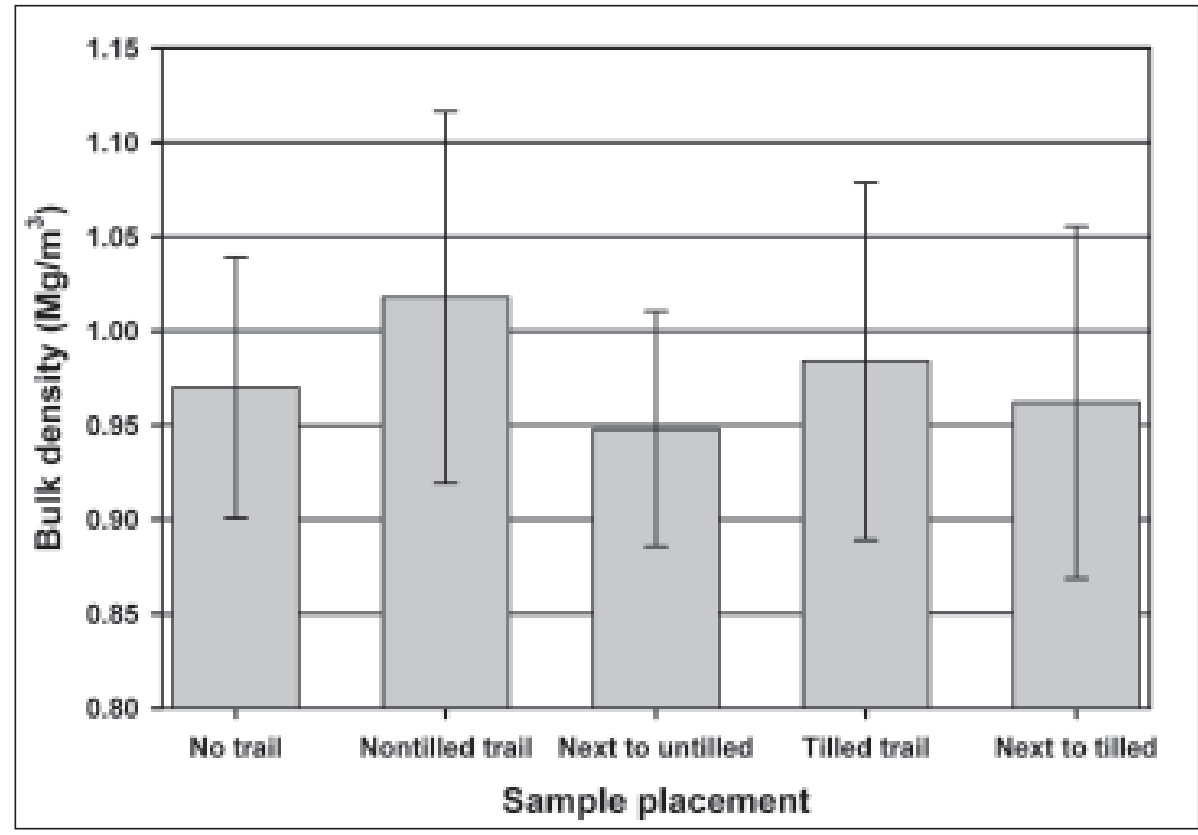

Figure 8-Means and standard deviations of soil bulk density 7 years after commercial thinning at Noti. 
Covariance analysis indicated that after-thinning growth was related to tree

After covariance adjustment, growth of nontilled trees averaged greater than tilled or nontrail trees.
BA before thinning $(\mathrm{p}=0.001)$, and that the three treatments differed in average 7 -year BA growth per tree $(\mathrm{p}=0.02$, table 10$)$. After covariance adjustment, growth of nontilled trees averaged 13 percent greater than that of nontrail trees and 22 percent greater than that of tilled trees. The 90-percent confidence interval (CI) for tilled and nontilled means do not overlap.

A second covariance analysis using after-thinning CSI as the covariate confirmed an anticipated negative relation between tree growth and local competition after thinning $(\mathrm{p}=0.06$, table 11$)$. As tabulated below, trees beside nontilled trails averaged less competition than control trees or those beside tilled trails:

\section{Competitive Stress Index}

\begin{tabular}{lcccc}
\cline { 2 - 5 } Treatment & Mean & Coefficient of Variation & Minimum & Maximum \\
\hline Nontilled & 191 & 17.8 & 150 & 284 \\
Tilled & 212 & 19.7 & 133 & 291 \\
No trail & 217 & 19.8 & 135 & 319
\end{tabular}

After adjustment to a common CSI, growth of trail-side trees averaged 8 to 14 percent greater than control trees (table 11), but adjusted treatment means were not statistically significant $(\mathrm{p}=0.48)$.

Table 10-Statistical significance of no trail, nontilled, and tilled skid trails on mean basal area (BA) growth per tree after commercial thinning at Noti, using tree BA before thinning as a covariate

\begin{tabular}{lrrcr}
\hline Factor & D.f. & M.s. & F-value & \multicolumn{1}{c}{ P } \\
\hline Regression & 1 & 305.90 & 118.6 & 0.001 \\
Treatment (T) & 2 & 9.86 & 3.82 & .025 \\
Trail within T (error 1) & 10 & 2.27 & - & - \\
Error (2) & 103 & 2.58 & - & - \\
Total & 116 & & &
\end{tabular}

Adjusted means and 90-percent confidence interval ${ }^{a}$

\begin{tabular}{lrrc} 
Treatment & \multicolumn{2}{c}{$\begin{array}{c}\text { Mean basal area } \\
\text { growth }\left(\text { in }^{2} / \text { year }\right)\end{array}$} & $\begin{array}{c}\text { Relative } \\
\text { percentage }\end{array}$ \\
\cline { 2 - 4 } Nontilled & $5.86 \mathrm{a}$ & $5.35-6.34$ & 113 \\
No trail & $5.20 \mathrm{ab}$ & $4.75-5.64$ & 100 \\
Tilled & $4.72 \mathrm{~b}$ & $4.23-5.20$ & 91 \\
\hline
\end{tabular}

$-=$ not applicable.

${ }^{a}$ Treatment means followed by the same letter are not significantly different based on Bonferroni test $(\mathrm{p} \leq 0.10)$. 
Table 11-Statistical significance of tree location (no trail, nontilled, and tilled skid trails) on mean basal area growth per tree after commercial thinning at Noti, using after-thinning competitive stress index as a covariate

\begin{tabular}{lrrrr}
\hline Factor & D.f. & M.s. & F-value & P \\
\hline Regression & 1 & 19.40 & 3.62 & 0.060 \\
Treatment (T) & 2 & 3.92 & 0.73 & .484 \\
Trail within T (error 1) & 10 & 5.24 & - & - \\
Error (2) & 103 & 5.36 & - & - \\
$\quad$ Total & 116 & & &
\end{tabular}

Adjusted means and 90-percent confidence interval $^{a}$

\begin{tabular}{lrrc} 
Treatment & \multicolumn{2}{c}{$\begin{array}{c}\text { Mean basal area growth } \\
\text { (in } 2 / \text { year) }\end{array}$} & $\begin{array}{c}\text { Relative } \\
\text { percentage }\end{array}$ \\
\cline { 2 - 4 } Nontilled & $5.78 \mathrm{a}$ & $4.99-6.57$ & 114 \\
Tilled & $5.46 \mathrm{a}$ & $4.73-6.19$ & 108 \\
No trail & $5.07 \mathrm{a}$ & $4.39-5.75$ & 100 \\
\hline
\end{tabular}

$-=$ not applicable.

${ }^{a}$ Treatment means followed by the same letter are not significantly different based on Bonferroni test $(\mathrm{p} \leq 0.10)$.

Percentages of estimated root zone trafficked by equipment were similar for trees next to nontilled or tilled trails (fig. 9), and trees along both tilled and nontilled trails averaged similar mean rates of growth after thinning. A subsample of trees with obvious root damage was evaluated separately, but this revealed no unique pattern of poorer growth with increasing severity of root damage $(\mathrm{p}=0.89$, table 12).

\section{Discussion}

Before seeking alternative explanations, we conditionally inferred from these data that cumulative impacts of various ground-based logging equipment in planned skid trails did not reduce b.h. growth of trail-side trees in the subsequent 7 to 11 years, and may have slightly increased average growth by about 3 to 15 percent among the three locations.

We assessed two alternative explanations for equal or greater b.h. growth of individual trees:

1. Position 1 trees may have had greater growth potential as evidenced by larger d.b.h. before thinning.

2. Position 1 trees may have had fewer competitors after release than position 2 trees. 


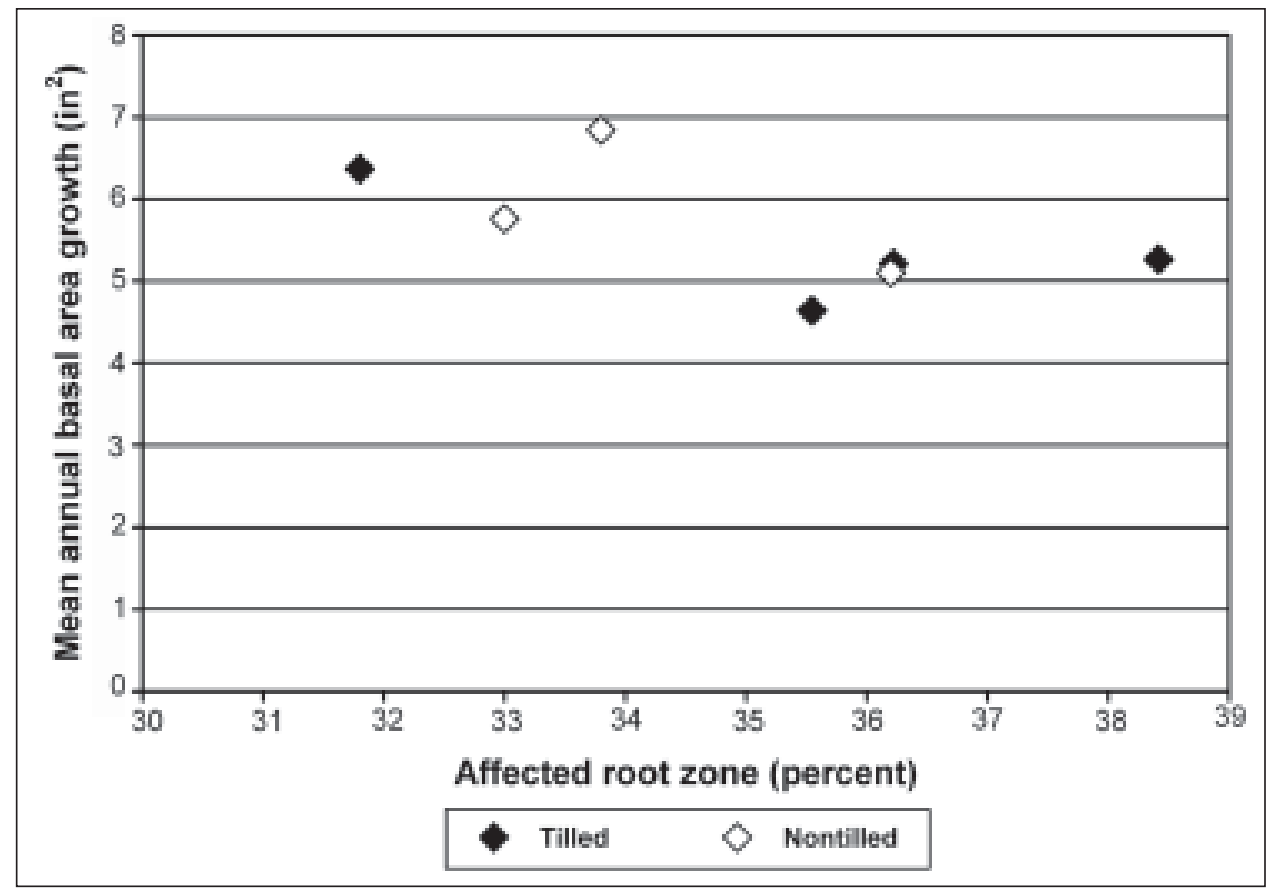

Figure 9-Mean annual basal area (BA) growth over 7 years related to percentage of estimated root zone impacted at Noti.

Table 12-Statistical significance of root-damage class after tillage of skid trails on basal area growth per tree after commercial thinning at Noti, using percentage area of root zone that was trafficked as a covariate

\begin{tabular}{lrccc}
\hline Factor & D.f. & M.s. & F-value & P \\
\hline Regression & 1 & 3.72 & 0.76 & 0.392 \\
Root damage class & 2 & 0.56 & .11 & .893 \\
Trail within class (error 1) & 9 & 3.36 & - & - \\
Error (2) & 24 & 4.91 & - & - \\
$\quad$ Total & 36 & & &
\end{tabular}

Adjusted means and 90-percent confidence interval ${ }^{a}$

\begin{tabular}{lccc} 
Damage class & $\begin{array}{c}\text { Mean basal area growth } \\
\text { (in } 2 / \text { year) }\end{array}$ & $\begin{array}{c}\text { Relative } \\
\text { percentage }\end{array}$ \\
\cline { 2 - 4 } Slight & $5.33 \mathrm{a}$ & $4.44-6.22$ & 100 \\
Moderate & $5.46 \mathrm{a}$ & $4.46-6.40$ & 102 \\
Severe & $5.89 \mathrm{a}$ & $4.36-7.42$ & 110 \\
\hline
\end{tabular}

$-=$ not applicable.

${ }^{a}$ Treatment means followed by the same letter are not significantly different based on Bonferroni test $(\mathrm{p} \leq 0.10)$. 


\section{Toledo South}

Trees next to trails averaged about 3 percent faster growth at b.h. than trees located farthest from the trails, and this difference was statistically significant $(\mathrm{p}=0.09)$.

\section{Greater growth potential?-}

Because the four treatment groups (position 1, position 2, 0-N, and 200-N) were similar in starting mean d.b.h., we reject this explanation.

\section{Fewer competitors?-}

This is unlikely. Because only neighboring rows of trees were cut, both position 1 (near trail) and position 2 trees were released to the same extent. No trees were cut within residual rows.

\section{Opinion-}

Theoretically, position 1 trees had two unique and potentially growth-reducing influences: nearby soil compaction and shallow rutting, and greater risk of bole damage from moving booms or extracted trees. We suspect that soil compaction was mitigated by slash deliberately placed on the trails; minimal bole damage was observed. We infer that equipment traffic did not affect tree growth at Toledo South. Bole damage during stem extractions was insignificant. Placing logging slash on all trails before trafficking probably mitigated soil compaction and rutting near trail-side trees.

\section{Bone Mountain A and B}

Breast-high growth of trees next to trails averaged about 14 percent more than growth of more distant trees at Bone Mountain A $(\mathrm{p}=0.02)$ and 11 percent more at Bone Mountain B $(\mathrm{p}=0.01)$ (tables 8 and 9).

\section{Greater growth potential?-}

Trees in position 1 at Bone Mountain A had after-thinning mean d.b.h. similar to those in position 2. At Bone Mountain B, however, d.b.h. after thinning averaged 6.6 in for position 1 and 6.8 in for position 2. We infer that some of the observed greater growth of position 2 trees at Bone Mountain B could be explained by somewhat larger tree size at start of the growth period.

\section{Fewer competitors?-}

In contrast to the strict row-thinning at Toledo South, some in-row trees were removed in both Bone Mountain plantations, especially in rows beside equipment routes. On all plots, position 1 trees consistently had fewer competitors than did 
Placing logging slash on trails before trafficking mitigated soil compaction and rutting. position 2 trees. We suspect that much of the 14- to 11- percent greater growth of position 1 trees is explained by their having fewer competitors, hence more growing space.

\section{Speculation-}

Benefits of greater release and fewer competing trees near position 1 trees more than offset any negative effects of equipment traffic at Bone Mountain A and B. As at Toledo South, placing logging slash on trails before trafficking mitigated soil compaction and rutting.

\section{Noti}

Patterns of tree response near skid trails at Noti were consistent with those at Toledo South and Bone Mountain A and B. Moreover, diameter before thinning and local competition are important variables for predicting growth response of individual trees to thinning.

\section{Greater growth potential?-}

Trees next to tilled trails initially averaged larger d.b.h. than nontrail and nontilled trees. Despite this indication of greater growth potential, observed mean growth of tilled trees averaged less than mean BA growth of both nontilled and nontrail trees (table 10). After covariance adjustment to mitigate these initial differences in starting d.b.h., average growth of trees near nontilled trails exceeded that of trees near tilled trails by about 22 percent and exceeded that of nontrail trees by about 13 percent.

\section{Less competition?-}

After-thinning growth was related to CSI, which was computed for each subject tree from d.b.h. and distances to neighboring trees. As expected, growth increased with decreasing CSI. Fortuitously, trees near nontilled trails averaged less CSI and less variable CSI after thinning than nontrail and tilled trees, which were similar in both mean values and variation. Despite covariance adjustment that used observed mean CSI to mitigate this advantage, after-thinning growth of nontilled trees still averaged 14 percent greater than nontrail and 6 percent greater than tilled trees (table $11)$.

\section{Inferences-}

That growth was increased by proximity to nontilled trails was surprising, yet consistent with results at Toledo South and Bone Mountain A and B. Large differences in growth among treatments owing to soil compaction was unlikely, because 
only small differences in soil BD were observed 7 years after treatment, and less than 40 percent of the assumed rooting area of individual trees was affected by equipment trails.

We suspect that trafficking the clay loam soil when dry, and limiting the extent of compacted area within the stand by using planned skid trails were effective tactics at Noti. Because increases in soil BD on trails were small, and trees near tilled trails averaged no or little response to thinning, tillage provided no clear benefit to residual trees, at least in the first 7 years after thinning and tillage.

Because of differing densiometers and depths of sampling, we have no reliable evidence for natural recovery from compaction in nontilled trails 7 years after logging. Published estimates of the time required for natural recovery of soils from compaction after forest harvesting differ considerably. Early studies examined only recovery of surface horizons, and more recent studies have included both surface and subsurface horizons. Determining the time for soils to recover their original $\mathrm{BD}$ retrospectively is especially problematic. Perhaps the greatest difficulty in assessing recovery rates is that compaction on trails is often preceded or accompanied by removal of surface soil. As a result, retrospective comparisons of BD in the surface soil of heavily trafficked areas versus that in nearby nontrafficked areas may actually compare compacted subsoil versus noncompacted surface soil of inherently lower BD. Given this invalid comparison, rate of apparent recovery is underestimated (Miller and others 2004).

\section{All Locations}

Further monitoring of soil conditions and tree growth on these sites could help us discern the duration of these interim patterns. An even greater need, however, is to conduct similar studies at other locations to determine where local site and treatment conditions have significant effects on residual tree growth. As experienced in this investigation, experimentally uncontrolled factors can confound interpretation of statistical tests.

\section{Potential Effects of Equipment Trails}

Soil in logging trails can be impacted several ways and with varying, hence poorly predictable, consequences for soil properties and subsequent tree growth. The consistent pattern among the four stands was that residual trees near equipment trails grew faster than those farther away. We consider additional explanations for this unexpected outcome.
Tillage provided no clear benefit to residual trees. 


\section{Soil disturbance-}

At our study locations, soil disturbance was largely compaction. Rutting and displacement were minimal at Toledo South and Bone Mountain A and B, because slash from $\log$ processing was deliberately placed on equipment trails. At Noti, soil disturbance, including compaction, on trails was minimized by dry-season logging even though traffic was concentrated on designated trails.

Effects of logging traffic on soil properties and tree growth are complex and depend on several factors, including (1) depths of slash and the forest floor; (2) soil texture (percentage of sand, silt, clay) and coarse fragments (gravel, cobbles, rock); (3) soil moisture content; (4) vehicle pressure, vibration, and traction; and (5) subsequent rate and effectiveness of natural remediation (freezing-thawing, wettingdrying, soil organisms, and vegetation). For example, coarse-textured soils dry rapidly, but they still can be susceptible to compaction via vehicle vibration. More importantly, compaction of coarse-textured soils can increase soil moisture-holding capacity by converting large pores to smaller pores, which retain moisture longer thereby benefiting tree growth in drier climates (Gomez and others 2002, Powers and Fiddler 1997). Although conversion to smaller pores in the fine-textured soils at our study sites (silt loam to clay loam textures), would not seem beneficial, a recent study (Ares and others 2005) reported both increased water-holding capacity and seedling growth on a silt loam soil (Boistfort series) in the Washington Coast Range where climate is more mesic than at study sites in northern California.

\section{Slash-}

Thinning slash was deliberately concentrated on equipment trails to cushion the physical impacts of equipment at Toledo South and Bone Mountain A and B. This mitigating practice has been shown to reduce compaction on similar soils (Allen and others 1997), and is likely to be most effective where slash remains deep enough to cushion impacts after repeated passes of equipment. Subsequently, slash can moderate soil temperature, reduce loss of soil moisture from evaporation, and reduce vegetative competition.

Slash can also affect subsequent nutrient availability for tree and vegetative growth. Initially, slash in contact with soil can reduce the amount of $\mathrm{N}$ available to plants by temporary incorporation into woody portions or microbes $(\mathrm{N}$-immobilization). Subsequent decomposition eventually recycles most of this $\mathrm{N}$ for plant uptake. Such recycling of $\mathrm{N}$ in slash placed on equipment trails is more likely to have enhanced tree growth at Bone Mountain A, because we measured response after an 11-year period after thinning (compared to 7 years at Toledo South). 
Moreover in earlier trials, trees at Bone Mountain A and B responded more strongly to $\mathrm{N}$ fertilization than at Toledo South (Miller and others 2001).

\section{Continued Effects of Nitrogen Fertilization}

Four years before commercial thinning, half of the plots in the plantations at Toledo South and Bone Mountain A and B were fertilized with $200 \mathrm{lb}$ N/acre. In the first 4 years after fertilization, fertilized plots at Toledo South averaged about 6 percent greater BA growth per acre than nonfertilized plots (Miller and others 2001). At Bone Mountain A, fertilized plots averaged 12.6 percent greater BA growth per acre than nonfertilized plots; response at Bone Mountain B averaged 9.2 percent (Miller and others 2001).

Where the 1994 thinnings had cut and left the same number and size of trees in both fertilized and nonfertilized plots, any difference in growth could result from continuing response to fertilizer, possibly from improved nutrition and by the continued benefit of larger or more efficient crowns of fertilized trees. We examined our results at each plantation to decide if those after-thinning conditions had been achieved. At Toledo South, a slightly smaller mean percentage of the original BA was cut in the fertilized plots (50 vs. 52), and the remaining BA per acre averaged about the same as in nonfertilized plots (table 13). In years 5 through 11 after fertilization, previously fertilized trees averaged 1 percent less growth at b.h. than nonfertilized. Moreover, response in BA per acre averaged -1.6 percent in the six fertilized plots (table 13). We infer no detectable continued response to urea fertilizer at this location.

At Bone Mountain A, a slightly larger mean percentage of the original BA was cut in fertilized plots (58 vs. 54 percent) and the residual stand averaged less BA (63.7 vs. $70.9 \mathrm{ft}^{2}$ ) (table 13). This should favor growth of individual trees but not growth per acre on the fertilized plots. Although response per tree averaged 10.5 percent, response per acre averaged only 0.3 percent because fewer trees remained on the fertilized plots (256 vs. 282 percent) (table 13). Evidence for continued response to urea is inconclusive.

At Bone Mountain B, mean percentage of cut BA and the remaining BA are similar for fertilized and nonfertilized plots (table 13). Although response per tree in the 5- to 15-year period after fertilization averaged -3.8 percent, BA response per acre averaged 5.6 percent. We conclude that continued response in the 11-year after-thinning period is minimal and inconclusive. 
Table 13-Mean annual growth per tree extended to annual growth per acre in the 11-year period after thinning of three plantations

\begin{tabular}{|c|c|c|c|c|c|c|c|c|c|}
\hline \multirow[b]{2}{*}{ Location } & \multirow[b]{2}{*}{ Fertilizer } & \multicolumn{2}{|c|}{ BA } & \multirow{2}{*}{$\begin{array}{l}\text { Growth } \\
\text { per tree }\end{array}$} & \multirow[b]{2}{*}{ Trees $^{\mathrm{b}}$} & \multirow{2}{*}{$\begin{array}{l}\text { Growth } \\
\text { per acre }\end{array}$} & \multicolumn{3}{|c|}{ Response per } \\
\hline & & cut & left & & & & tree & acre & acre $^{\mathrm{c}}$ \\
\hline & Lb N/acre & Percent & $F t^{2} /$ acre & $F t^{2}$ & No./acre & $F t^{2} /$ acre & -- & Percent & $t---$ \\
\hline \multirow{2}{*}{ Toledo South } & 0 & 52 & 93.0 & 0.0338 & 299 & 10.11 & - & - & - \\
\hline & 200 & 50 & 92.8 & .0335 & 297 & 9.95 & -0.9 & -1.6 & 6.3 \\
\hline \multicolumn{10}{|c|}{ Bone Mountain: } \\
\hline \multirow[t]{2}{*}{ A } & 0 & 54 & 70.9 & .0333 & 282 & 9.39 & - & - & - \\
\hline & 200 & 58 & 63.7 & .0368 & 256 & 9.42 & 10.5 & 0.3 & 12.6 \\
\hline \multirow[t]{2}{*}{ B } & 0 & 60 & 66.2 & .0340 & 245 & 8.33 & - & - & - \\
\hline & 200 & 59 & 65.8 & .0327 & 269 & 8.80 & -3.8 & 5.6 & 9.2 \\
\hline
\end{tabular}

- = not applicable.

${ }^{a}$ From tables 3, 6, and 7 .

${ }^{b}$ From tables 1 and 4 .

${ }^{c}$ In year 1 through 4 after fertilizer (Miller and others 2001, table 14).

\section{Conclusions}

- Commercial thinning of these 20- to 60-year-old Douglas-fir stands by using ground-based logging vehicles and planned skid trails usually on dry soils did not reduce, and probably slightly increased tree growth of trailside residual trees.

- At three plantations where half the plots were fertilized 4 years before thinning, tree response to adjacent trails was independent of the addition of $200 \mathrm{lb}$ N/acre as urea. Little evidence exists for continued response to urea in the after-thinning period ( 5 to 11 years).

- Quantifying the practical consequences of soil disturbance for subsequent tree growth is a complex challenge involving many interacting factors. Further research at other locations is warranted.

\section{Acknowledgments}

We thank Plum Creek Timberlands L.P. (for tree data, professional assistance, and financial support); Steve Duke, biometrician, for advice about statistical testing; Johan Hogervorst and Jesus Martinez-Ben, former Oregon State University graduate students who investigated the Noti location; and Ron Heninger, Pat Cunningham, Doug Robin, Robert Curtis, and M. Conner Fristoe for technical review of our draft manuscript. 


\section{Metric Equivalents}

1 inch $($ in) $=2.54$ centimeters

1 square inch $\left(\mathrm{in}^{2}\right)=6.45$ square centimeters

1 foot $(\mathrm{ft})=0.3048$ meter

1 mile $=1.6$ kilometers

1 pound per square inch $(\mathrm{Psi})=6.90 \mathrm{kPa}$

1 pound per acre $(\mathrm{lb} / \mathrm{acre})=1.12$ kilograms per hectare

1 pound per square inch $\left(\mathrm{lb} / \mathrm{in}^{2}\right)=70.3$ grams per square centimeters $\left(\mathrm{g} / \mathrm{cm}^{2}\right)$

1 pound per cubic foot $\left(\mathrm{lb} / \mathrm{ft}^{2}\right)=0.0160$ gram per cubic centimeter or megagrams

per cubic meter $\left(\mathrm{Mg} / \mathrm{m}^{3}\right)$

1 square foot $\left(\mathrm{ft}^{2}\right)=0.093$ square meter

1 acre $=0.4047$ hectare

1 pound $(\mathrm{lb})=454$ grams

1 tree per acre $(\mathrm{TPA})=2.47$ trees per hectare

1 thousand broad feet $(\mathrm{mbf})=$ about 4.5 cubic meters

\section{Literature Cited}

Adams, P.W. 2005. Research and policies to address concerns about soil compaction from ground-based timber harvest in the Pacific Northwest: evolving knowledge and needed refinements. In: Matzka, P.J., ed. Proceedings, Council on Forest Engineering Conference on Soil, Water and Timber Management. Corvallis, OR: Council on Forest Engineering: 22-30.

Allen, M.M.; Adams, P.W.; Kellogg, L.D. 1997. Soil bulk density and cone index after harvester and penetrometer cone index after harvester and forwarder traffic over different slash depths in the Oregon Cascades. Project completion report, Weyerhaeuser Foundation. Corvallis, OR: Forest Engineering Department, Oregon State University. $42 \mathrm{p}$.

Andrus, C.W.; Froehlich, H.A. 1983. An evaluation of four implements used to till compacted forest soils in the Pacific Northwest. Res. Bull. 45. Corvallis, OR: Forest Research Laboratory, College of Forestry, Oregon State University. $12 \mathrm{p}$.

Ares, A.; Terry, T.; Miller, R.E.; Anderson, H.W.; Flaming, B.L. 2005. Groundbased forest harvesting effects on soil physical properties and Douglas-fir growth. Soil Science Society of America Journal. 69: 1822-1832. 
Arney, J.D. 1973. Tables quantifying competitive stress on individual trees. Information Rep. BC-X-78. Victoria, BC: Department of the Environment, Canadian Forest Service, Pacific Forest Research, Canada. 10 p. plus appendix, tables, and figures.

Curtis, R.O. 1982. A simple index of stand density for Douglas-fir. Forest Science. 28(1): 92-94.

Davis, S. 1990. Effectiveness of a winged subsoiler in ameliorating a compacted clayey forest soil. Western Journal of Applied Forestry. 5(4): 138-139.

Froehlich, H.A. 1979. The effect of soil compaction by logging on forest productivity. Final report to the USDI Bureau of Land Management, contract 53500CT4-5(N). Corvallis, OR: School of Forestry, Oregon State University. 40 p.

Gomez, A.; Powers, R.F.; Singer, M.J.; Horwath, W.R. 2002. Soil compaction effects on growth of young ponderosa pine following litter removal in California's Sierra Nevada. Soil Science Society of America Journal. 66: 1334-1343.

Haagen, J.T. 1989. Soil survey of Coos County, Oregon. Portland, OR: U.S, Department of Agriculture, Soil Conservation Service. 269 p. and maps.

Han, H.-S.; Kellogg, L.D. 2000. Damage characteristics in young Douglas-fir stands from commercial thinning with four timber harvesting systems. Western Journal of Applied Forestry. 15(1): 27-33.

Heninger, R.; Scott, W.; Dobkowski, A.; Miller, R.; Anderson, H.; Duke, S. 2002. Soil disturbance and 10-year growth response of coast Douglas-fir on nontilled and tilled skid trails in the Oregon Cascades. Canadian Journal of Forest Research. 32: 233-246.

Hogervorst, J.B. 1994. Soil compaction from ground-based thinning and effects of subsequent skid trail tillage in a Douglas-fir stand. Corvallis, OR: Forest Engineering Department, Oregon State University. 83 p. M.S. thesis.

King, J.E. 1966. Site index curves for Douglas-fir in the Pacific Northwest. Weyerhaeuser For. Pap. 8. Centralia, WA: Weyerhaeuser Company. 49 p.

Martinez-Ben, J. 2000. Tillage of compacted soil in a thinned Douglas-fir stand in western Oregon: soil density and residual tree growth seven years after treatment. Corvallis. OR: Forest Engineering Department, Oregon State University. 65 p. M.S. thesis. 
McNeel, J.F.; Ballard, T.M. 1992. Analysis of site stand impacts from thinning with a harvester-forwarder system. Journal of Forest Engineering. 4: 23-27.

Miller, R.E.; Colbert, S.R; Morris, L.A. 2004. Effects of heavy equipment on physical properties of soils and on long-term productivity: a review of literature and current research. Technical Bulletin 887. Research Triangle Park, NC: National Council for Air and Stream Improvement, Inc. 76 p.

Miller, R.E.; Scott, W.; Hazard, J.W. 1996. Soil compaction and conifer growth after tractor yarding at three coastal Washington locations. Canadian Journal of Forest Research. 26: 225-236.

Miller, R.E.; Smith, J.; Anderson, H. 2001. Detecting response of Douglas-fir plantations to urea fertilizer at three locations in the Oregon Coast Range. Res. Pap. PNW-RP-433. Portland, OR: U.S. Department of Agriculture, Forest Service, Pacific Northwest Research Station. 20 p.

Murphy, G. 1982. Soil damage associated with production thinning. New Zealand Journal of Forestry Science. 12: 281-292.

Patching, W.R. 1987. Soil survey of Lane County area, Oregon. Portland, OR: U.S. Department of Agriculture, Soil Conservation Service. 369 p. plus maps.

Powers, R.F.; Fiddler, G.O. 1997. The North America long-term soil productivity study: progress through the first 5 years. In: Proceedings 18th annual forest vegetation management conference. Redding, CA: Forest Vegetation Management Conference: $88-102$.

SAS Institute. 1999. SAS/STAT user's guide. Version 8. Cary, NC: Statistical Analysis Systems Institute, Inc. 3884 p. Vol. 2.

\section{U.S. Department of Agriculture, Natural Resources Conservation Service} [USDA NRCS]. 1997. Soil survey of Lincoln County area, Oregon. Portland, OR. 158 p. 


\begin{tabular}{|ll|}
\hline \multicolumn{2}{|c|}{ Pacific Northwest Research Station } \\
Web site & http://www.fs.fed.us/pnw \\
Telephone & $(503) 808-2592$ \\
Publication requests & $(503) 808-2138$ \\
FAX & $(503) 808-2130$ \\
E-mail & pnw_pnwpubs@fs.fed.us \\
Mailing address & Publications Distribution \\
& Pacific Northwest Research Station \\
& P.O. Box 3890 \\
& Portland, OR 97208-3890 \\
\hline
\end{tabular}


This Page Left Blank Intentionally 
This Page Left Blank Intentionally 
This Page Left Blank Intentionally 


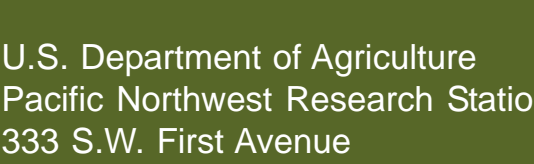

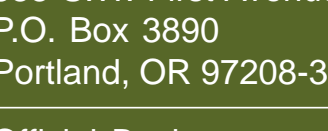

